\title{
Recent Developments in the Facile Bio-Synthesis of Gold Nanoparticles (AuNPs) and Their Biomedical Applications
}

This article was published in the following Dove Press journal: International Journal of Nanomedicine

\author{
Kar Xin Lee \\ Kamyar Shameli ${ }^{1}$ \\ Yen Pin Yew' \\ Sin-Yeang Teow $\mathbb{D}^{2}$ \\ Hossein Jahangirian (iD ${ }^{3}$ \\ Roshanak Rafiee- \\ Moghaddam (iD) ${ }^{3}$ \\ Thomas J Webster $\mathbb{D}^{3}$ \\ 'Department of Environmental \\ Engineering and Green Technology, \\ Malaysia-Japan International Institute of \\ Technology, Universiti Teknologi Malaysia, \\ Kuala Lumpur 54I00, Malaysia; \\ ${ }^{2}$ Department of Medical Sciences, School \\ of Healthcare and Medical Sciences \\ (SHMS), Sunway University, Jalan \\ Universiti, Bandar Sunway 47500, \\ Selangor Darul Ehsan, Malaysia; \\ ${ }^{3}$ Department of Chemical Engineering, \\ 313 Snell Engineering Center, \\ Northeastern University, Boston, \\ MA, USA
}

\begin{abstract}
Gold nanoparticles (AuNPs) are extensively studied nanoparticles (NPs) and are known to have profound applications in medicine. There are various methods to synthesize AuNPs which are generally categorized into two main types: chemical and physical synthesis. Continuous efforts have been devoted to search for other more environmental-friendly and economical large-scale methods, such as environmentally friendly biological methods known as green synthesis. Green synthesis is especially important to minimize the harmful chemical and toxic by-products during the conventional synthesis of AuNPs. Green materials such as plants, fungi, microorganisms, enzymes and biopolymers are currently used to synthesize various NPs. Biosynthesized AuNPs are generally safer for use in biomedical applications since they come from natural materials themselves. Multiple surface functionalities of AuNPs allow them to be more robust and flexible when combined with different biological assemblies or modifications for enhanced applications. This review focuses on recent developments of green synthesized AuNPs and discusses their numerous biomedical applications. Sources of green materials with successful examples and other key parameters that determine the functionalities of AuNPs are also discussed in this review.
\end{abstract}

Keywords: biosynthesis, green materials, gold nanoparticles, AuNPs, biomedical applications

\section{Introduction}

Nanotechnology is the combination of science, engineering and technology at the nanoscale typically ranging from 1 to $100 \mathrm{~nm}$. This technology has been applied to many fields such as chemistry, biology, physics, material science, engineering and medicine. Nanomaterials can be classified primarily into two categories: naturally and synthetically fabricated nanomaterials. Natural nanomaterials include viruses, substances in bone matrices (such as calcium phosphate crystals) and corals while synthetic nanomaterials can be further divided into four families: metal-based, carbon-based, dendrimers, and nanocomposites. Metal-based synthetic nanomaterials are nanosized metals such as copper $(\mathrm{Cu})$, iron $(\mathrm{Fe})$, palladium $(\mathrm{Pt})$, gold $(\mathrm{Au})$, aluminium $(\mathrm{Al})$, zinc $(\mathrm{Zn})$ and silver (Ag). The properties of metallic NPs support various applications including serving as catalysts, sensing components, optical devices and biomedical applications. ${ }^{1}$ Carbon-based nanomaterials are composed of carbon in the form of hollow spheres such as fullerenes, ellipsoids such as graphite, and cylindrical nanotubes. These nanomaterials have led to the manufacturing of batteries and ultrasensitive sensors. ${ }^{2}$ Dendrimers (which are also known as arborols or starburst polymers) are nanosized polymers built from branched units to form highly ordered three-dimensional tree-like
Correspondence: Kamyar Shameli;

Hossein Jahangirian

Tel +6 017 344-3492;

$+1617860-8429$

Email kamyarshameli@gmail.com;

kamran.jahangirian@gmail.com 
structures. Dendrimers are often used as catalysts since they have numerous chain ends present on the surface of nanomaterials that allow for specific chemical reactions. ${ }^{3}$ Nanocomposites are the combination of any nanomaterials, usually along with nanoparticles (NPs). By combining various nanomaterials in a nanocomposite, several properties can be incorporated into a single application such as electrochemical sensors and biosensors, ${ }^{4}$ tissue engineering, ${ }^{5}$ stem cell culture engineering and regenerative medicine. ${ }^{6}$

The production of nanomaterials via different approaches can be generally divided into two categories: "bottom-up" and "top-down". The bottom-up approach is the assembly of a combination of building blocks through chemical or biological methods. Bottom-up synthesis plays an important role in the fabrication of nanostructures as it results in products with more uniform chemical composition. However, this method tends to introduce internal stress, hence increasing the possibility of surface defects and contaminations. On the other hand, top-down synthesis is defined as the break-down of bulk materials into smaller structures. This process makes the bulk production of nanomaterials easier, but a major drawback is the imperfection of the resulting surface structures and the significant crystallographic damage that may result. These limitations highly affect the physical properties and surface chemistry of nanomaterials, ultimately influencing their intended applications if not well-controlled. ${ }^{7}$

The synthesis of inorganic NPs can be achieved through conventional methods such as chemical and physical methods. Chemical synthesis involves using chemical reagents (such as sodium borohydride) to act as reducing and stabilizing agents, whereas physical methods involve using high external forces (such as temperature and pressure) to break down materials into NPs. However, toxic by-products that endanger living organisms and the environment are produced when using conventional synthesis methods. ${ }^{8}$ Using chemical solvents during the synthesis process causes difficulty in the extraction of nanoparticles later on and presents significant hurdles to medical applications. The synthesis of amphiphilic colloids of CdS and noble metal nanoparticles require such pursuits. ${ }^{9}$ Moreover, the additional of precursor materials (such as polyvinyl alcohol causes) may lead to cytotoxicity of healthy cells when the nanoparticles are used as drug delivery agents. Studies have also found that nanoparticles affect the functions of the heart and the vasculature, which needs to be carefully assessed. ${ }^{10}$

Hence, a new and inventive approach for the green, environmentally-friendly, synthesis of NPs has been introduced and termed "biosynthesis". ${ }^{11}$ Biosynthesis focuses on the reduction and elimination of the use or generation of hazardous toxic substances in chemical compounds, especially those used in industrial applications. ${ }^{12}$ Raw materials used in biosynthesis are renewable. Biosynthesis methods use a safer and non-toxic route for the production of biocompatible NPs which are highly applicable for numerous medical applications. ${ }^{13}$ Nanoparticles synthesized using this method produce many important pharmaceutical molecules that can be effectively applied for targeted drug delivery because toxic chemicals are eliminated. ${ }^{10,14}$ Moreover, as will be discussed, many studies have not only highlighted less toxic nanoparticles using such biosynthesis approaches, but their properties for preventing, diagnosis, and treating diseases are also improved.

This review paper discusses the synthesis of gold NPs (AuNPs) via green synthesis. The production of green AuNPs is described briefly and different bio-reductant and capping agents such as terpenoids, phenolic compounds, proteins, polysaccharides and nicotinamide adenine dinucleotide (NAD) are introduced. Then, a variety of sources of green materials are discussed. A table showing the use of different natural herbaceous parts is given and other green materials (such as fungi, bacteria, enzymes and biopolymers) are discussed. Finally, the potential biomedical applications of AuNPs in the biomedical field (including use as therapeutic agents, drug delivery agents, sensing agents and antimicrobial agents) are also discussed.

\section{Synthesis of Green Gold Nanoparticles}

AuNPs are some of the most extensively studied NPs among all noble metal NPs because of their multiple surface functionalities and unique surface plasmon resonance that can be utilized in many aspects. ${ }^{15,16}$ There are many applications of AuNPs in society today (such as heavy metal determination, ${ }^{17}$ catalysis, ${ }^{18}$ optical sensing and imaging ${ }^{19}$ ). More importantly, AuNPs can be combined with different nano-biological assemblies such as oligonucleotides, antibodies, and proteins to enhance their functions. The binding of these biomolecules with AuNPs alters surface plasmon resonance (SPR), conductivity and redox behavior, hence increasing their flexibility in terms of modification. This section discusses the production of AuNPs using a biological method, which is also commonly known as green synthesis. Green materials that can act as reducing agents are plant, fungus, bacterial, enzymes and biopolymers as shown in Figure 1. 


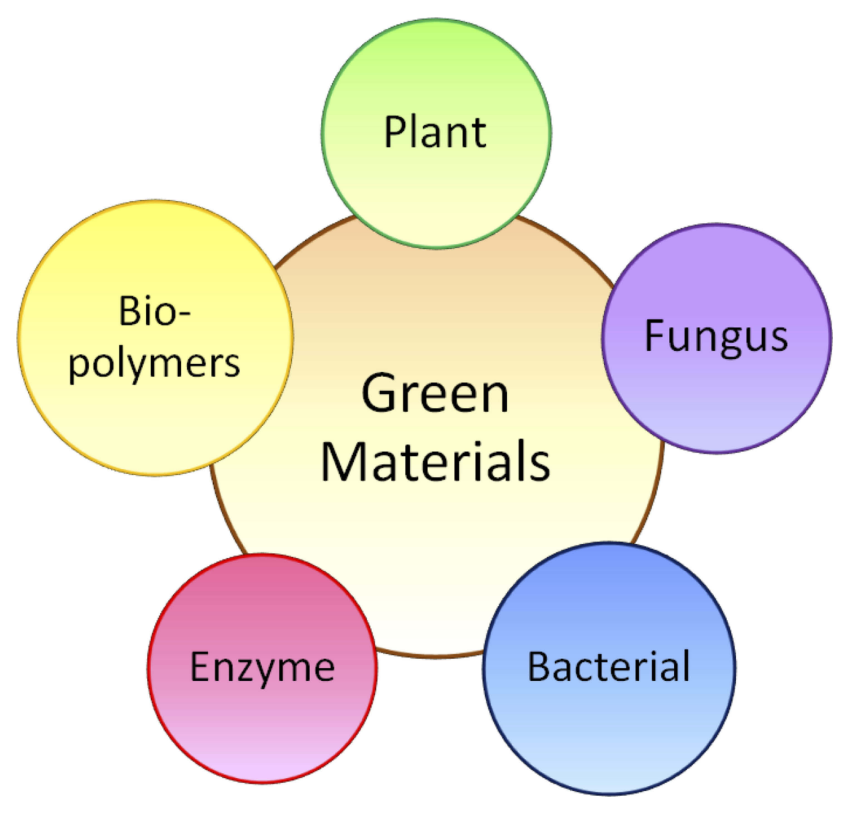

Figure I The types of green materials that can synthesize gold nanoparticles.

\section{Production via Green Synthesis}

The production of AuNPs by green synthesis is simple and facile. The NPs can be produced under a moderate environment without using elevated temperatures or pressures. The most common production method is the extracellular nanoparticle production method. ${ }^{20}$ The production is initiated by tetrachloroaurate salt $\left(\mathrm{HAuCl}_{4}\right)$. After mixing, the mixture is stirred on a stirrer to produce NPs. The color change to red or purplish indicates the successful production of AuNPs. This is then followed by centrifugation and drying of the NPs for characterization and use. Figure 2 shows a simple illustration of the production of AuNPs.

Notably, the simplicity of the production process highly varies depending on the choice of green materials. Green materials (such as bacteria, fungi and enzymes) require delicate preparation steps. First, these organisms need to be cultured or propagated in order to obtain sufficient starting materials for the reaction. ${ }^{21}$ Extra steps may be required, such as ultra-sonication and/or the use of enzyme separation processes to obtain purified green materials. These preparations require more complicated and meticulous steps which make the production process laborious and tedious. Table 1 shows some of the advantages and disadvantages of different green materials used to make AuNPs.

Differences in parameters and reaction environment have a significant impact on the physicochemical properties of AuNPs (such as their shape, size and surface charge) which must be ideally controlled for their biomedical applications. Parameters (such as concentration of $\mathrm{HAuCl}_{4}$, amount of green extract, reaction time, temperature and $\mathrm{pH}$ ) must be optimally evaluated to obtain desirable characteristics of AuNPs. For instance, an increase in the amount of $\mathrm{HAuCl}_{4}$ and green extract often results in an increased size and irregular shape of the NPs due to agglomeration. ${ }^{16}$ For example, the size of AuNPs increased from $6 \mathrm{~nm}$ to $100 \mathrm{~nm}$ as the concentration of Lantana camara linn leaf extract increased from 100 $\mathrm{mgl}^{-1}$ to $500 \mathrm{mgl}^{-1}{ }^{25}$ Similarly, the increase of reaction time and temperature generally results in the same outcome. ${ }^{26}$ Notably, the reaction time highly depends on the reducing ability of the green materials. Garcinia mangostana peel extracts managed to synthesize AuNPs within minutes whereas AuNPs were produced only after 72 hrs using a Lantana camara berry extract. ${ }^{27,28}$ While an increase of temperature could accelerate the reaction time, it tends to induce agglomeration of NPs. ${ }^{29}$ The green synthesis of AuNPs from Cannabbis sativa was optimized

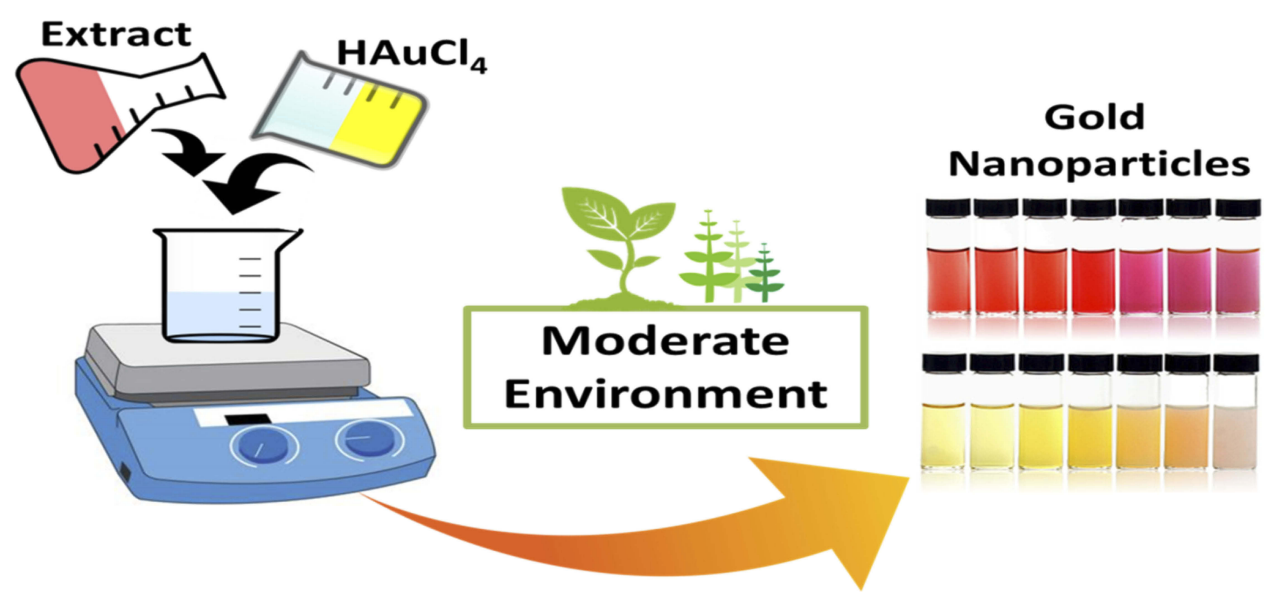

Figure 2 A simple illustration for the production of gold nanoparticles via green methods. 
Table I The Advantages and Disadvantages of Different Green Materials for the Synthesis of Gold Nanoparticles

\begin{tabular}{|c|c|c|c|c|}
\hline $\begin{array}{l}\text { Green } \\
\text { Materials }\end{array}$ & Advantages & Disadvantages & Applications & References \\
\hline Plants & $\begin{array}{l}\text { Synthesis method is simple and facile. It is easy to } \\
\text { control the size and shape of the NPs by altering } \\
\text { the reaction parameters and the reduction of } \\
\text { NPs is relatively rapid and cost effective. }\end{array}$ & $\begin{array}{l}\text { It is difficult to determine the reactive } \\
\text { components in plants because plant } \\
\text { extracts contain many organic compounds. }\end{array}$ & $\begin{array}{l}\text { Biomedical } \\
\text { applications, removal } \\
\text { of dyes and heavy } \\
\text { metals, catalysts. }\end{array}$ & $22-24$ \\
\hline Fungi & $\begin{array}{l}\text { It is possible to scale up the production of } \\
\text { NPs using fungi because they are able to } \\
\text { secrete large amounts of protein. Fungi are } \\
\text { easier to culture as compared to other } \\
\text { microorganisms. }\end{array}$ & $\begin{array}{l}\text { Delicate preparation steps are needed to } \\
\text { obtain mycelia free culture filtrates and it } \\
\text { is difficult to genetically manipulate } \\
\text { eukaryotic organisms to produce specific } \\
\text { enzymes. Some species are pathogenic. }\end{array}$ & $\begin{array}{l}\text { Antioxidants, } \\
\text { catalyst for } \\
\text { pollutant } \\
\text { degradation. }\end{array}$ & $94,95,100$ \\
\hline Bacteria & $\begin{array}{l}\text { Some species are resistant against heavy } \\
\text { metals, thus, they can be exploited for } \\
\text { biological metal recovery. Purer NPs are } \\
\text { produced. }\end{array}$ & $\begin{array}{l}\text { Not economical as bacteria culturing is } \\
\text { tedious. The reduction process is also } \\
\text { slow, ranging from hours to days. }\end{array}$ & $\begin{array}{l}\text { Drug delivery } \\
\text { agent, antibacterial } \\
\text { agent. }\end{array}$ & $21,48,103$ \\
\hline Enzyme & $\begin{array}{l}\text { Enzymes are commercially available in pure } \\
\text { form. The purification of NPs is easier. }\end{array}$ & $\begin{array}{l}\text { Some enzymes are expensive to purchase } \\
\text { whereas the enzyme extraction process } \\
\text { from microbes may be time consuming. }\end{array}$ & $\begin{array}{l}\text { Anticancer agent, } \\
\text { antimicrobial } \\
\text { agent. }\end{array}$ & $52,104,105$ \\
\hline Biopolymers & $\begin{array}{l}\text { Biopolymers consist of a variety of } \\
\text { functional groups that can produce NPs } \\
\text { and have a good combination of properties. }\end{array}$ & $\begin{array}{l}\text { Different biopolymers have different } \\
\text { reducing ability, therefore, it is necessary } \\
\text { to test the reducing ability of the } \\
\text { biopolymers. }\end{array}$ & $\begin{array}{l}\text { Antifilarial } \\
\text { therapeutics, } \\
\text { catalyst, antioxidants, } \\
\text { biosensors. }\end{array}$ & $106,111,112,114$ \\
\hline
\end{tabular}

at $100^{\circ} \mathrm{C}$, and agglomeration occurred when the temperature further increased above $100^{\circ} \mathrm{C}^{30}$ The shape of the nanoparticles was not directly affected by the reducing compounds but was affected by the concentration of the starting materials and temperature. As the concentration of the reducing agent increased, the shape of the AuNPs tended to increase and some developed irregular and flower shapes due to agglomeration. ${ }^{31,32}$

\section{Bio-Reductant and Capping Agents}

Green materials can act as both reducing and stabilizing agents for the synthesis of AuNPs. In brief, biomolecules from green materials first reduce gold (iii) ions to zero-valent gold. Then, NP stabilization (as mediated by the biomolecules) can occur by covering the outer surface of the NPs through agglomeration. This mechanism of AuNP synthesis proposed by Anuradha and Abbasi is shown in Figure 3. ${ }^{33}$

When choosing the right green materials, those with high antioxidant properties are often favored because they contain a high abundance of reactive compounds that could take part in the reduction and stabilizing processes. For example, grape pomace was utilized by González-Ballesteros et al for the production of AuNPs due to its antioxidant properties. ${ }^{34}$
Other kinds of berries that are rich in antioxidant content have also been chosen for the synthesis of AuNPs. ${ }^{35}$ Secondly, polar and water-soluble biocompounds are preferred for the reaction process. Gan et al extracted various compounds from palm oil mill effluence using different solvents and they showed that flavonoids, proteins, reducing sugars and water-soluble alkaloids that are present in water extracts were all capable of reducing AuNPs. Besides, small amounts of AuNPs were formed using an ethyl acetate extract which contained polyphenols and alkaloids, meanwhile no reaction occurred using a hexane extract containing non-polar compounds. ${ }^{36}$ Stability of the green synthesized AuNPs is relatively stable and sufficient for different applications. Sundararajan et al synthesized Artemisia vulgaris mediated AuNPs that could be a treatment against $A$. aegypti dengue fever. The stability of the AuNPs was indicated by a zeta potential value of $-19.3 \mathrm{mV}$, thus, having a strong negative electric charge stable under a wide range of $\mathrm{pH}$ values. ${ }^{37}$ AuNPs synthesized by Actinidia deliciosa showed a stability of $-22.3 \mathrm{mV}$. This high potential value is because of the uniform distribution and homogeneity of the particles. ${ }^{38}$ Two types of AuNPs were synthesized using different parts of Cannabis sativa. Both of them showed a negative zeta 


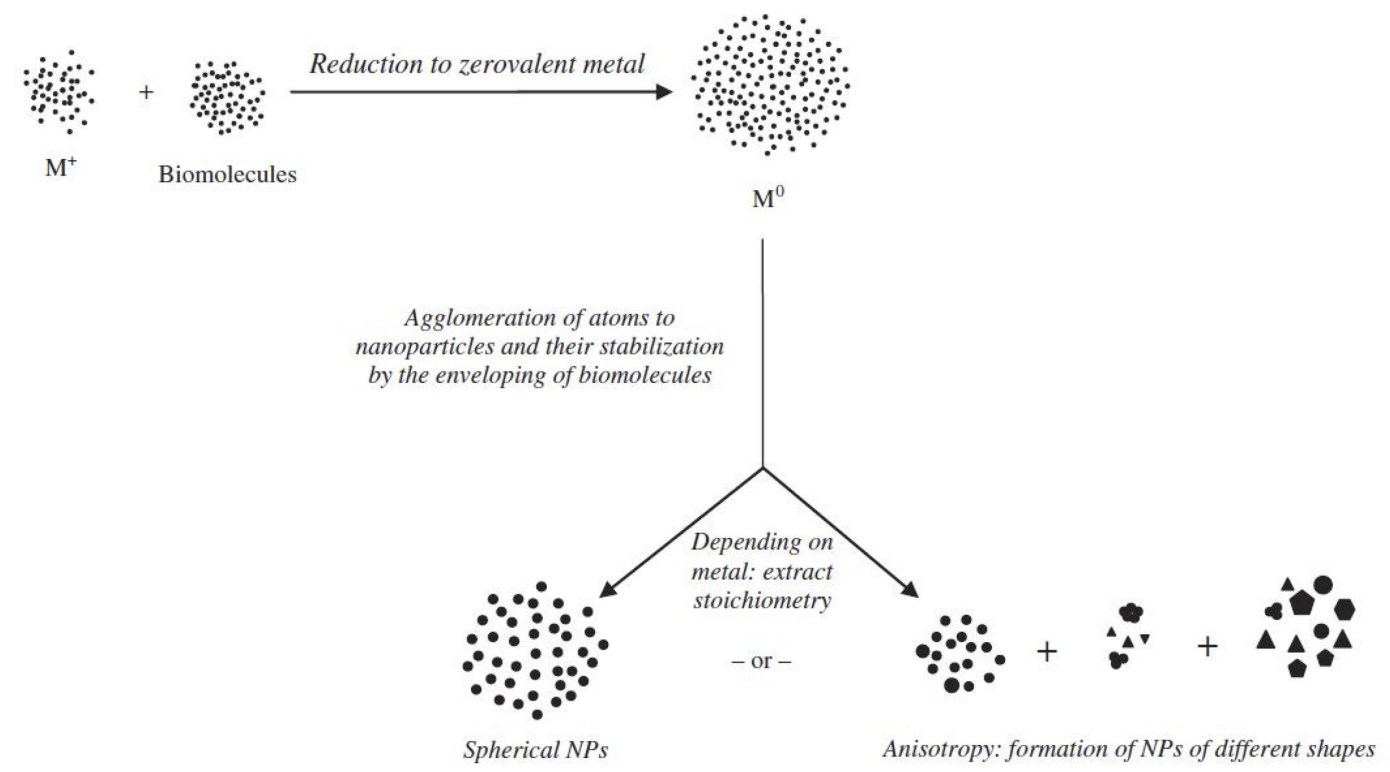

Figure 3 Proposed mechanism for the reduction of gold nanoparticles where $M^{+}$is a gold (iii) ion while $M^{0}$ is a zero valent gold. ${ }^{33}$ "Reprinted from Journal of Advanced Research, 6, Anuradha, J, T Abbasi, and S. Abbasi, An eco-friendly method of synthesizing gold nanoparticles using an otherwise worthless weed pistia (Pistia stratiotes L.), 7II-720, Copyright (2015), with permission from Elsevier."

potential of $-12.3 \mathrm{mV}$ and $-20.6 \mathrm{mV}$, respectively. High negativity of the zeta potential value showed that the AuNPs possessed sufficient surface charge to remain electrostatically stable and resistant to aggregation. ${ }^{30}$ Other biomolecules derived from living organisms that can be used to stabilize NPs are described below.

\section{Terpenoids}

Terpenoids or isoprenoids are the largest groups of natural products derived from five-carbon isoprene units. They can be assembled and modified with methyl groups or oxygen atoms. Song et al speculated that terpenoids from Magnolia kabus can serve as surface-active molecules to stabilize AuNPs based on the presence of a $1736 \mathrm{~cm}^{-1}$ band by FTIR that corresponds to carbonyls groups. Meanwhile, amide III and amide I bands of proteins were observed at 1227 and $1629 \mathrm{~cm}^{-1}$, respectively. This finding suggested that AuNPs are surrounded by proteins and metabolites such as terpenoids. ${ }^{39}$ On the other hand, terpenoids were detected from the absorption peaks on FTIR spectrum at $1700-1600 \mathrm{~cm}^{-1}$ when Elavazhagan et al synthesized AuNPs using Memecylon edule leaf extracts. The peaks corresponded to $\mathrm{C}=\mathrm{C}$ or aromatic groups when compared with a previous report. ${ }^{40}$

\section{Phenolic Compounds}

Phenolic compounds or phenols are one or more hydroxyl groups bonded directly to an aromatic ring. Functional derivatives (such as esters, methyl esters, and glycosides) can attach to this phenolic compound (such as simple phenols, phenolic acids, hydroxycinnamic acid and flavonoids) which are found in most natural antioxidant agents. ${ }^{41}$ For example, Alam et al found that the aqueous extract from Murraya koenigii Spreng contained gallic acid, duercetin, quercetin and quercetin-3-glucoside during the synthesis of AuNPs. ${ }^{8}$ Qualitative phytochemical analysis was performed by Vijayakumar et al to determine the classes of constituents present in the peel extract of Musa paradisiaca. This analysis showed that flavonoids, quinones, phenols, steroids, phytosteroids and tannins were found in the extract. ${ }^{42}$ On the other hand, A. nilotica bark extract was rich in phenolics with hydroxyl and carboxyl groups. The high nucleophilic property of aromatic rings in phenols might be the reason for the general chelating ability of the compounds. Hence, phenol groups involved in the reduction of $\mathrm{HAuCl}_{4}$ are those that occur through the oxidation of hydroxyl to carbonyl groups. ${ }^{43}$

\section{Proteins}

Proteins are made up of amino acids that link together in long chains leading to different structures and functions of proteins. Carboxylate groups found on proteins can serve as a surfactant for NP synthesis. This property enables the proteins to attach on the surface of NPs and stabilize them through electrostatic bonding. From the FTIR results by Mukherjee et al, the stretching frequency at $1244.07 \mathrm{~cm}^{-1}$ disappeared after the synthesis of AuNPs. This suggested that the amide III groups in proteins took part in the reduction of AuNPs. This result was further confirmed by SDS gel electrophoresis, suggesting that both 
low and high molecular weight proteins are responsible for the formation and stabilization of AuNPs. ${ }^{44}$ Other work by Patra et al suggested that low molecular weight proteins $(\sim 12 \mathrm{kDa}$ and $\sim 22 \mathrm{kDa}$ ) played a role in the reduction process as the bands disappeared in SDS gels after the production of NPs. ${ }^{45}$

\section{Polysaccharides}

Simple sugars are monosaccharides which are the basic building block of carbohydrates. Some examples of simple sugars are glucose, fructose and galactose. When they link together by glycosidic links, they form polysaccharides. Polysaccharides are important to living organisms for their structure and storage. Galanga rhizome tested positive in a Fehling's test indicating that it contains high sugars. These sugars can serve as the reagents in the reduction of gold (iii) ions to NPs. ${ }^{46}$ Similarly, Noruzi et al demonstrated that rose petal extracts are rich in sugars and can be used for the reduction of AuNPs. The sugar content was qualitatively measured through a dinitrosalicyclic acid (DNS) test and Bradford method. ${ }^{47}$ On the other hand, Sathiyanarayanan et al utilized microbial exopolysaccharides that were secreted during the growth of bacteria to synthesize AuNPs. During IR, a peak on the spectrum was observed at $3442 \mathrm{~cm}^{-1}$ showing that the microbial exopolysaccharides contained abundant hydroxyl groups. ${ }^{48}$

\section{Nicotinamide Adenine Dinucleotide (NAD)}

NAD is an enzyme ubiquitously found in all living organisms. It plays a pivotal role in redox reactions during metabolism and can be present in two forms: oxidized $(\mathrm{NAD}+)$ and reduced (NADH) forms. During the production of AuNPs from living organisms such as bacteria and fungi, NADH plays an important part in the oxidation of gold (iii) ions. For example, Pseudomonas denitrificans secretes NADH-dependant enzymes, such as nitrate reductase. Mewada et al showed that nitrate reductase activity in Pseudomonas denitrificans decreased after the synthesis of AuNPs. ${ }^{49}$ On the other hand, Shah et al demonstrated that NADH- and NADH-dependent enzymes might act as a scaffold or nucleating agent. The activity of reductase in the supernatants was reduced after the formation of AuNPs from $1.21 \mu \mathrm{mole} / \mathrm{min} / \mathrm{mL}$ to $0.23 \mu \mathrm{mole} / \mathrm{min} / \mathrm{mL}^{21}$

\section{Green Materials}

There is an emerging trend to utilize biological materials as the strategy to produce NPs especially for biomedical applications. This is because they are non-toxic and environmental friendly. Therefore, green synthesis has been introduced for this purpose. Green synthesis is the utilization of a set of principles that reduces or eliminates the use or generation of hazardous substances in the design, manufacturing and application of chemical products. The development and design of effective and eco-friendly green chemistry methods for the synthesis of metal based NPs are gaining interest because the preparation of NPs using conventional methods have endangered the environment and organisms around the world. Practicing green methods results in more advantages. First of all, it is very simple, clean and efficient. It is also very eco-friendly and economically cheap where bioreagents (such as bacteria, ${ }^{50}$ fungus, ${ }^{51}$ enzymes, ${ }^{52}$ and plants) play a role as both reducing and stabilizing agents. For example, platinum NPs were produced using metal ion reducing bacteria Shewanella algae. ${ }^{53}$ Besides that, the mushroom species Flammulina velutipe was able to produce AuNPs with sizes less than $20 \mathrm{~nm}^{54}$ and the presence of the NADPH enzyme was able to reduce NPs. ${ }^{55}$ This method is also relatively safe and non-toxic because the use of hazardous materials and chemicals is minimal or even totally avoided. Moreover, non-toxic biosynthesized NPs are mostly biocompatible and highly applicable for biomedical applications. ${ }^{45}$ Green synthesis can be used to produce NPs at a large scale. Extreme external conditions (like high energy and pressure) are avoided and, thus, less energy is consumed. ${ }^{56}$

Three main concerns for green production methods must be evaluated based on green chemistry perspectives. They are the selection of the solvent medium, the reducing agent and the use of non-hazardous stabilizers. Examples of green solvents are water, ethanol and other non-toxic solvents. Green materials that are obtained from nature can act as a reducing agent for safer production procedures. Most green materials possess a stabilizing ability due to the presence of different reactive groups (such as carboxyl and hydroxyl groups) in the extract.

Bio-based synthesis creates highly stable and well characterized NPs. Some aspects that need to be taken into consideration are optimal reaction conditions, types of reducing agent, selection of biocatalyst, conditions for cell growth and enzyme activity. ${ }^{57}$

\section{Plants}

Plants are some of the greenest materials available for NP synthesis due to the presence of many organic compounds which can act as reducing and stabilizing agents. Some examples of reactive compounds are flavonoids, amino acids, carboxylic acids, ketones, phenols and proteins. It is also one of the simplest approaches because this method 
does not require an aseptic environment. ${ }^{58}$ The reaction can be started easily by contacting the starting materials. The reaction environment is economical and low in cost as it does not need high temperatures or pressures. The reaction is also easily scalable because the shape and size of NPs can be finely tuned by varying the reaction conditions as compared to other methods. ${ }^{20}$ Figure 4 shows some of the examples of plants that have been used to specifically synthesize AuNPs.

A mixture of metal salts and plant extracts has allowed one to form AuNPs at room temperature. This reaction often takes a few minutes to a few hours. The reaction time needed is faster as compared to other green materials. This reaction can be scaled up by varying the reaction conditions, especially the reaction temperature. Every part of the plant can be utilized. ${ }^{59}$ Leaves are the most common part as compared to other parts like bark, fruit, seed, flower, root and peel. Figure 5 gives a brief insight into the parts of plants that can be used for nanoparticle synthesis whereas Table 2 summarizes the biogenic fabrication of NPs and their applications when synthesized from various parts of plants. Changes in parameters control the size and shape of the NPs while the extract from different parts of the plants provides organic compounds that act as the reducing agent. The composition of organic compounds in different parts of the plants varies slightly, thus, giving a different effect to control the synthesis of AuNPs. For example, the total content of phenolic acids in the peel (5028 $\mathrm{mg}$ per $\mathrm{kg}$ ) of Garcinia mangostana is much higher than the fruit $(266 \mathrm{mg}$ per kg). ${ }^{60}$ Therefore, the production of AuNPs occurred within minutes using the peel from Garcinia mangostana. ${ }^{27}$

\section{Leaves}

Salix alba or white willow tree leaves have been collected by Ul Islam et al for the synthesis of AuNPs. Different parameters (such as $\mathrm{pH}(2-13)$, temperature $\left(80^{\circ} \mathrm{C}\right)$ and concentration of sodium chloride $(50-300 \mu \mathrm{L}))$ were altered to determine the effect of external conditions toward the stability of NPs. Under acidic conditions, AuNPs were stable. However, when the $\mathrm{pH}$ increased gradually, the NPs became less stable. Peak broadening and red shifts were noted at $\mathrm{pH} 12$ and 13. At different volumes of salt, AuNPs also showed remarkable stability. The NPs were relatively unstable at elevated temperatures. ${ }^{19}$

Leaves of a date palm have also been able to reduce $\mathrm{HAuCl}_{4}$ to AuNPs. The size of the spherically shaped NPs was in the range of 32 to $45 \mathrm{~nm}$. The leaves of a date palm were extracted by maceration with $70 \%$ ethanol/water in $100 \mathrm{~mL}$. Then, an extraction process was carried out under room temperature for 7 days to obtain the extract necessary for
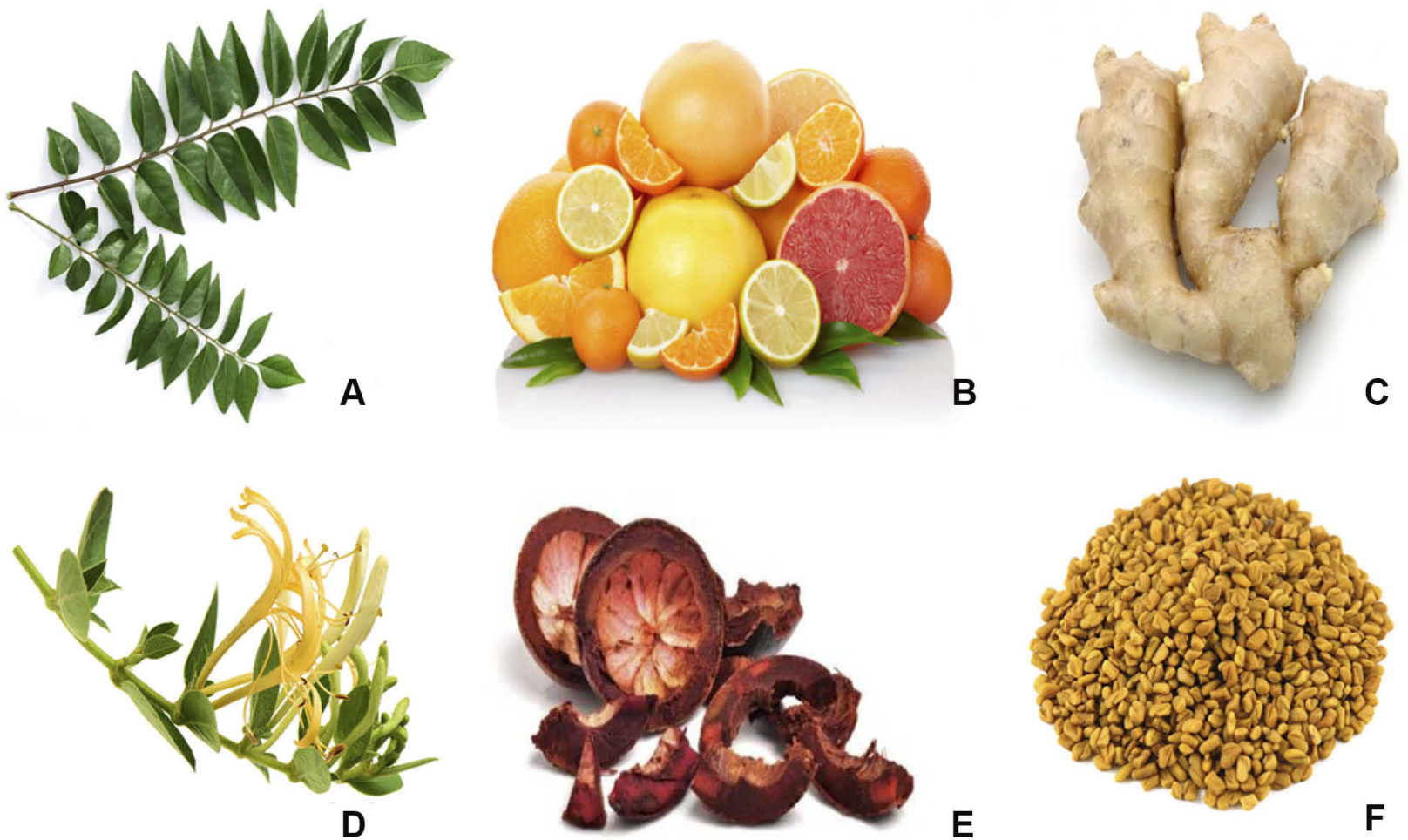

Figure 4 Some examples of plants: (A) Murraya koenigii Spreng, (B) Citrus, (C) Zingiber officinale, (D) Lonicera Japonica, (E) Garcinia mangostana and (F) abelmoschus esculentus used to synthesize gold nanoparticles. 


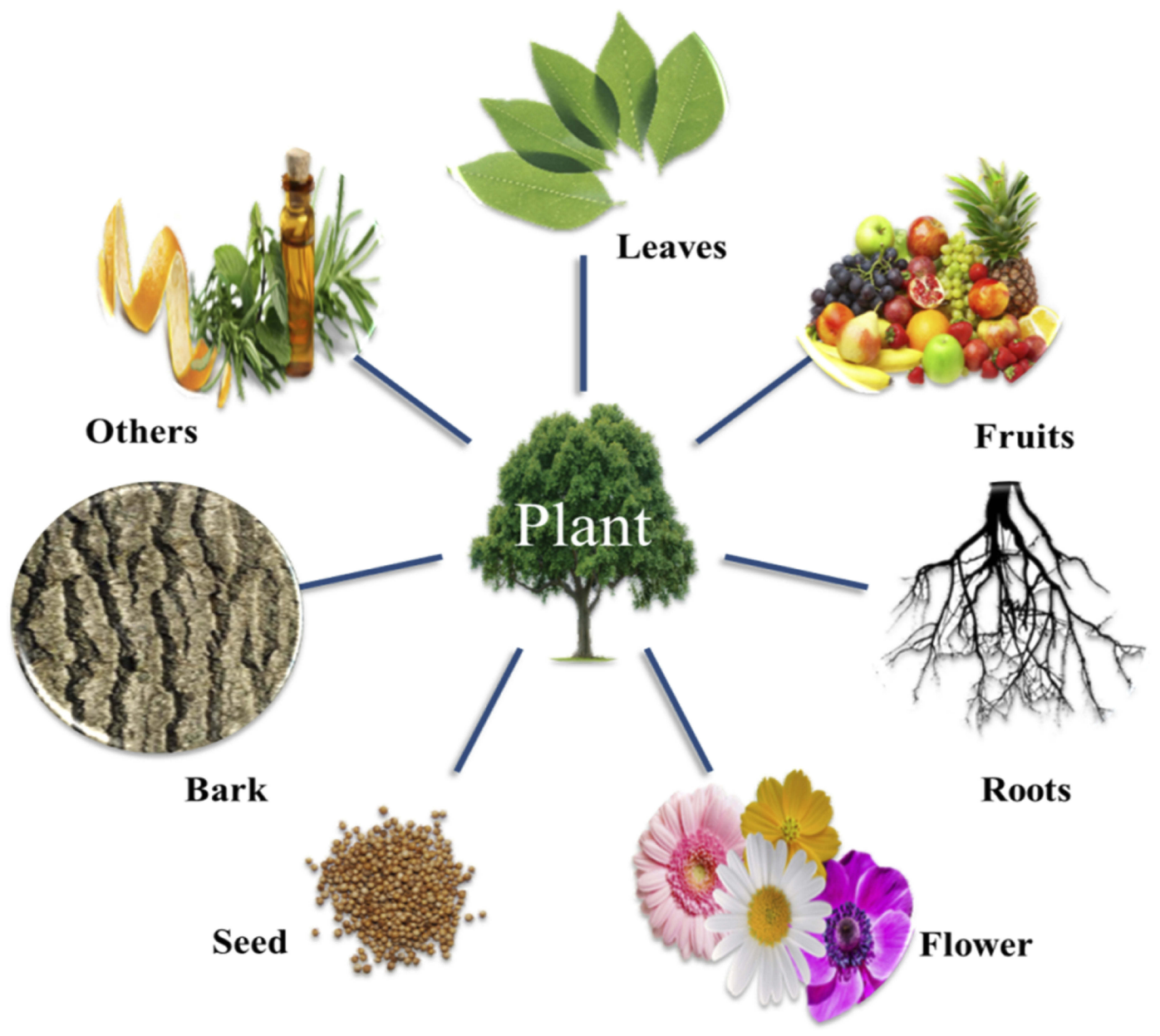

Figure 5 Every part of a plant can be utilized as a green material for AuNP synthesis.

synthesis. Increasing the volume of an extract gave a blue shift in UV-vis spectroscopy and also sped up the reaction. As the volume of the plant extract increased, the size of the AuNPs became smaller, that is from $45 \mathrm{~nm}$ reduced to $32 \mathrm{~nm}$. This phenomenon may be due to the nucleation rate. A faster nucleation rate produced monodispersed and smaller particles. ${ }^{83}$ Figure 6 shows TEM images and histograms of the size of the synthesized AuNPs.

\section{Fruits}

Different parts of a plant can be used to produce NPs beside leaves. The utilization of fruits, roots and flowers are some other common parts. Berries and citrus fruits are common examples of green reducing agents because they are rich in antioxidants. Opris et al used elderberry, Sambucus nigra, to synthesize AuNPs. They suggested that the fruit extract was high in phenolic compounds at a reading of $6.85 \mathrm{~g} \mathrm{GAE} / \mathrm{L}$ and proposed that phenolic compounds were responsible for the reduction and stabilization process. ${ }^{84}$ Blackberries and blueberries which are rich in antioxidants also have the same ability. NPs produced by blueberries were spherical and triangular in shape with a size of 50 to $150 \mathrm{~nm}$ while blackberryproduced AuNPs were oblong NPs with an average size of 100 $\mathrm{nm}^{35}$

\section{Rhizomes}

Huo et al used medicinal plants to synthesize AuNPs. Root extracts of Glycyrrhiza uralensis, or commonly known as Chinese liquorice, have been extensively used as a traditional medicine for anti-viral, antioxidant and antiinflammatory purposes due to the presence of glycyrrhizin and flavonoids. The reaction of $\mathrm{HAuCl}_{4}$ with Chinese liquorice extract occurred rapidly within 4 mins. Spherical AuNPs were obtained with a size of $12.25 \mathrm{~nm} .{ }^{85}$ Galangal ginger was capable to reduce $\mathrm{HAuCl}_{4}$ into AuNPs according to Mahakham et al's research. A Au SPR band was observed at $536 \mathrm{~nm}$ indicating the formation of AuNPs. The SPR band increased in intensity when the reaction time increased from $30 \mathrm{mins}$ to $24 \mathrm{hrs}$. The size of the NPs ranged from 10 to $30 \mathrm{~nm}$ with a spherical shape. SAED 
Table 2 Green Synthesized Gold Nanoparticles Using Different Parts of Plants

\begin{tabular}{|c|c|c|c|c|c|c|c|}
\hline $\begin{array}{l}\text { Part } \\
\text { Used }\end{array}$ & Plant & Reactive Compound & Size $(\mathrm{nm})$ & Shape & $\begin{array}{l}\text { Reaction } \\
\text { Time }\end{array}$ & Applications & References \\
\hline \multirow[t]{11}{*}{ Leaves } & $\begin{array}{l}\text { Artemisia vulgaris } \\
\text { (Mugwort) }\end{array}$ & Polyphenols, flavonoids, terpenoids & $50-100$ & $\begin{array}{l}\text { Spherical, triangular, } \\
\text { hexagonal }\end{array}$ & $24 \mathrm{~h}$ & $\begin{array}{l}\text { Larvicidal activity } \\
\text { against Aedes } \\
\text { larvae }\end{array}$ & 37 \\
\hline & $\begin{array}{l}\text { Clitoria ternatea } \\
\text { (Asian } \\
\text { pigeonwings) }\end{array}$ & $\begin{array}{l}\text { Alcoholic, amine groups, halocompou- } \\
\text { nds }\end{array}$ & 100 & Rod & $24 \mathrm{~h}$ & $\begin{array}{l}\text { Antibacterial, } \\
\text { antioxidant }\end{array}$ & 150 \\
\hline & $\begin{array}{l}\text { Artocarpus } \\
\text { hirsutus (Wild } \\
\text { jack) }\end{array}$ & Polyphenols, flavonoids, terpenoids & $5-40$ & Spherical & $6 \mathrm{~h}$ & Anticancer & 136 \\
\hline & $\begin{array}{l}\text { Justicia glauca } \\
\text { (Thaasi } \\
\text { murungai) }\end{array}$ & $\begin{array}{l}\text { Lignans [(+)-pinoresinol, }(+)- \\
\text { medioresinol], alkaloids, flavonoids, } \\
\text { steroids (sitosterol-3-0-glucoside), } \\
\text { terpenoids }\end{array}$ & 32 & Hexagonal, spherical & Ih & $\begin{array}{l}\text { Electrode for } \\
\text { selective } \\
\text { voltammetry }\end{array}$ & 17 \\
\hline & $\begin{array}{l}\text { Murraya koenigii } \\
\text { Spreng (Curry } \\
\text { leaves) }\end{array}$ & $\begin{array}{l}\text { Polyphenols, quercetin, quercetin- } \\
\text { 3-glucoside, flavonoids }\end{array}$ & $20-40$ & Spherical & $152 \mathrm{mins}$ & Fluorescent marker & 8 \\
\hline & $\begin{array}{l}\text { Terminalia arjuna } \\
\text { (Arjun tree) }\end{array}$ & $\begin{array}{l}\text { Arjunetin, leucoanthoc-yanidins, } \\
\text { hydrolyzable tannins }\end{array}$ & $20-50$ & Spherical & $15 \mathrm{mins}$ & Plant tissue culture & 61 \\
\hline & $\begin{array}{l}\text { Memecylon } \\
\text { umbellatum (Iron } \\
\text { wood) }\end{array}$ & $\begin{array}{l}\text { Protein, saponins, polyphenols, } \\
\text { carbohydrate }\end{array}$ & $15-25$ & $\begin{array}{l}\text { Spherical, triangular, } \\
\text { hexagonal }\end{array}$ & $18 \mathrm{~h}$ & - & 62 \\
\hline & $\begin{array}{l}\text { Coreopsis } \\
\text { lanceolate }\end{array}$ & Antioxidants like sugars, flavonoids & $20-30$ & $\begin{array}{l}\text { Spherical, quasi } \\
\text { spherical }\end{array}$ & $15 \mathrm{mins}$ & $\begin{array}{l}\text { Detections of } \\
\text { aflatoxins }\end{array}$ & 140 \\
\hline & Olive & $\begin{array}{l}\text { Proteins, oleoropein, apigenin- } \\
\text { 7-glucoside, luteolin-7-glucoside }\end{array}$ & $50-100$ & $\begin{array}{l}\text { Triangular, spherical, } \\
\text { hexagonal }\end{array}$ & $20 \mathrm{mins}$ & - & 63 \\
\hline & $\begin{array}{l}\text { Cassia auriculata } \\
\text { (Matura tea tree) }\end{array}$ & Polysaccharides, flavonoids & $15-25$ & $\begin{array}{l}\text { Spherical, triangular, } \\
\text { hexagonal }\end{array}$ & $10 \mathrm{mins}$ & - & 64 \\
\hline & $\begin{array}{l}\text { Mangifera indica } \\
\text { (Mango) }\end{array}$ & Terpenoids, flavonoids, thiamine & $17-20$ & Spherical & $2 \mathrm{mins}$ & - & 65 \\
\hline \multirow[t]{5}{*}{ Fruits } & $\begin{array}{l}\text { Lantana camara } \\
\text { (Wild sage) }\end{array}$ & $\begin{array}{l}\text { Ursolic acid, iridoid glycosides, mono- } \\
\text { and sesquiterpe-nes, flavonoids }\end{array}$ & $150-300$ & Triangle & $72 \mathrm{~h}$ & - & 28 \\
\hline & $\begin{array}{l}\text { Citrus maxima } \\
\text { (Pomelo) }\end{array}$ & $\begin{array}{l}\text { Polypeptides/proteins, terpene, } \\
\text { ascorbic acid }\end{array}$ & $15-35$ & Spherical & $5 \mathrm{mins}$ & Catalyst & 66 \\
\hline & $\begin{array}{l}\text { Sterculia } \\
\text { acuminate (Pola } \\
\text { plant) }\end{array}$ & Phenolic compounds & $9.37-38.12$ & Spherical & $4 \mathrm{mins}$ & Catalyst & 58 \\
\hline & $\begin{array}{l}\text { Citrus (Lemon, } \\
\text { tangerine, } \\
\text { orange) }\end{array}$ & Citric acid, proteins & $\begin{array}{l}32.3,43.4 \\
56.7\end{array}$ & Spherical, triangular & $10 \mathrm{mins}$ & - & 67 \\
\hline & Pear & Sugars, amino acids, proteins & $20-400$ & $\begin{array}{l}\text { Triangular, hexagonal, } \\
\text { polyhedral }\end{array}$ & $20 \mathrm{mins}$ & - & 68 \\
\hline
\end{tabular}

(Continued) 
Table 2 (Continued).

\begin{tabular}{|c|c|c|c|c|c|c|c|}
\hline $\begin{array}{l}\text { Part } \\
\text { Used }\end{array}$ & Plant & Reactive Compound & Size $(\mathrm{nm})$ & Shape & $\begin{array}{l}\text { Reaction } \\
\text { Time }\end{array}$ & Applications & References \\
\hline \multirow[t]{5}{*}{ Rhizome } & Yam bean & - & $200-400$ & Triangular & $24 \mathrm{~h}$ & $\begin{array}{l}\text { Photodynamic and } \\
\text { photo thermal } \\
\text { therapy }\end{array}$ & 69 \\
\hline & $\begin{array}{l}\text { Acorus calamus } \\
\text { (Sweet flag) }\end{array}$ & $\begin{array}{l}\text { Asarone, caryophylle-ne, isoasarone, } \\
\text { methyl isoeugenol, safrole }\end{array}$ & 10 & Spherical & - & UV-blocking agent & 70 \\
\hline & Turmeric & $\begin{array}{l}\text { Phenolic (curcumin), triterpenoids, } \\
\text { alkaloid, sterols }\end{array}$ & $5-60$ & Oblong spherical & - & - & 35 \\
\hline & $\begin{array}{l}\text { Zingiber officinale } \\
\text { (Ginger) }\end{array}$ & $\begin{array}{l}\text { Oxalic acid, ascorbic acid, } \\
\text { phenylpropa-noids, zingerone }\end{array}$ & $10-20$ & $\begin{array}{l}\text { Spherical, triangular, } \\
\text { truncated triangular, } \\
\text { hexagonal }\end{array}$ & $20 \mathrm{mins}$ & Antibacterial & 71 \\
\hline & $\begin{array}{l}\text { Panax ginseng } C \text {. } \\
\text { A. Meyer (Korean } \\
\text { red ginseng) }\end{array}$ & $\begin{array}{l}\text { Saponin glycoside (ginsenoside), } \\
\text { polysaccha-rides, flavones, peptide } \\
\text { glycans }\end{array}$ & $2-40$ & Spherical & $2.5 \mathrm{~h}$ & Anticancer & 72 \\
\hline \multirow[t]{2}{*}{ Flower } & $\begin{array}{l}\text { Lonicera Japonica } \\
\text { (Japanese } \\
\text { honeysuckle) }\end{array}$ & Amino acids & 8 & Triangular, tetrahedral & Ih & - & 73 \\
\hline & $\begin{array}{l}\text { Nyctanthes } \\
\text { arbortristis (Night } \\
\text { flowering } \\
\text { jasmine) }\end{array}$ & alkaloids, flavonoids & $15-25$ & spherical & $30 \mathrm{mins}$ & - & 74 \\
\hline \multirow[t]{3}{*}{ Peels } & $\begin{array}{l}\text { Musa paradisiaca } \\
\text { (Banana) }\end{array}$ & $\begin{array}{l}\text { Phenolic compounds, gallocatechin, } \\
\text { dopamine }\end{array}$ & 50 & Spherical & $20 \mathrm{mins}$ & $\begin{array}{l}\text { Antibacterial, } \\
\text { anticancer }\end{array}$ & 42 \\
\hline & $\begin{array}{l}\text { Mangifera indica } \\
\text { Linn (Mango) }\end{array}$ & Phenols, carboxylic acids & $3.26-21.68$ & Quasi-spherical & $25 \mathrm{mins}$ & $\begin{array}{l}\text { Non-cytotoxic to } \\
\text { normal cells }\end{array}$ & 75 \\
\hline & $\begin{array}{l}\text { Terminalia arjuna } \\
\text { (Arjun tree) }\end{array}$ & Polyphenols & 60 & $\begin{array}{l}\text { Triangular, hexagonal, } \\
\text { pentagonal }\end{array}$ & $20 \mathrm{mins}$ & - & 76 \\
\hline \multirow[t]{2}{*}{ Seed } & Cocoa & Polyphenols & $150-200$ & spherical & - & $\begin{array}{l}\text { photothermal } \\
\text { therapy }\end{array}$ & 77 \\
\hline & $\begin{array}{l}\text { Abelmoschus } \\
\text { esculentus (Okra) }\end{array}$ & $\begin{array}{l}\text { Proteins, polysaccha-rides, } \\
\text { glycoprotein }\end{array}$ & $45-75$ & $\begin{array}{l}\text { Spherical, uneven } \\
\text { shape }\end{array}$ & $10 \mathrm{mins}$ & Antifungal & 78 \\
\hline \multirow[t]{3}{*}{ Bark } & $\begin{array}{l}\text { Guazuma } \\
\text { ulmifolia (Bay } \\
\text { cedar) }\end{array}$ & $\begin{array}{l}\text { Tannins, proanthocya-nidins, } \\
\text { precocene, catechins }\end{array}$ & $20-25$ & Spherical & $10 \mathrm{mins}$ & $\begin{array}{l}\text { Catalyst, DNA } \\
\text { binding, } \\
\text { antibacterial, } \\
\text { antifungal, } \\
\text { anticancer }\end{array}$ & 156 \\
\hline & Willow tree & Tannins, alkanoids, flavonoids, alkaloids & 15 & Spherical & $30 \mathrm{mins}$ & $\begin{array}{l}\text { Colorimetric } \\
\text { sensor }\end{array}$ & 142 \\
\hline & $\begin{array}{l}\text { Acacia nilotica } \\
\text { (Gum Arabic } \\
\text { tree) }\end{array}$ & $\begin{array}{l}\text { Protein, phenols, tannins, terpenoids, } \\
\text { saponins }\end{array}$ & $10-50$ & $\begin{array}{l}\text { Unshaped, quasi- } \\
\text { spherical }\end{array}$ & $10 \mathrm{mins}$ & $\begin{array}{l}\text { Electrochemical } \\
\text { sensor }\end{array}$ & 43 \\
\hline
\end{tabular}

(Continued) 
Table 2 (Continued).

\begin{tabular}{|c|c|c|c|c|c|c|c|}
\hline $\begin{array}{l}\text { Part } \\
\text { Used }\end{array}$ & Plant & Reactive Compound & Size $(\mathrm{nm})$ & Shape & $\begin{array}{l}\text { Reaction } \\
\text { Time }\end{array}$ & Applications & References \\
\hline $\begin{array}{l}\text { Others } \\
\text { pulp }\end{array}$ & $\begin{array}{l}\text { Capsicum annuum } \\
\text { var. grossum } \\
\text { (Green pepper) }\end{array}$ & Proteins, carbohydrates & $6-37$ & $\begin{array}{l}\text { Triangular, hexagonal, } \\
\text { quasi-spherical }\end{array}$ & $10 \mathrm{mins}$ & Catalyst & 32 \\
\hline Biomass & $\begin{array}{l}\text { Momordica } \\
\text { cochinchinensis } \\
\text { (Lour.) Spreng } \\
\text { (Gac) }\end{array}$ & Proteins & $10-80$ & $\begin{array}{l}\text { Spherical, oval, } \\
\text { triangular }\end{array}$ & $12 \mathrm{~h}$ & Photo catalyst & 79 \\
\hline Galls & $\begin{array}{l}\text { Pistacia } \\
\text { integerrima } \\
\text { (Zebra wood) }\end{array}$ & $\begin{array}{l}\text { Monoterpenes, triterpenoids, sterols, } \\
\text { dihydromal-valic acid }\end{array}$ & $20-200$ & Grain like & - & $\begin{array}{l}\text { Enzyme inhibition, } \\
\text { muscle relax, } \\
\text { sedative activities }\end{array}$ & 157 \\
\hline Nut & $\begin{array}{l}\text { Areca catechu } \\
\text { (Pinang palm) }\end{array}$ & $\begin{array}{l}\text { Polyphenols, fats, proteins, } \\
\text { carbohydrate, flavonoids }\end{array}$ & Spherical & 13.70 & $5 \mathrm{~h}$ & $\begin{array}{l}\text { Catalyst, } \\
\text { antioxidant, } \\
\text { antibacterial, } \\
\text { anticancer }\end{array}$ & 80 \\
\hline Latex & $\begin{array}{l}\text { Hevea brasiliensis } \\
\text { (Para rubber } \\
\text { tree) }\end{array}$ & isoprene, proteins & 50 & Spherical, triangular & $30 \mathrm{mins}$ & - & 81 \\
\hline $\begin{array}{l}\text { Palm oil } \\
\text { mill } \\
\text { effluent }\end{array}$ & Palm oil & $\begin{array}{l}\text { Proteins, flavonoids, reducing sugars, } \\
\text { alkaloids }\end{array}$ & 13-25 & Spherical & $\mathrm{lh}$ & $\begin{array}{l}\text { Removal of } \\
\text { mercury }\end{array}$ & 36 \\
\hline $\begin{array}{l}\text { Whole } \\
\text { plant }\end{array}$ & $\begin{array}{l}\text { Macrotyloma } \\
\text { uniflorum (Horse } \\
\text { gram) }\end{array}$ & Proteins, carbohydrate, antioxidant & $14-17$ & Spherical & - & - & 82 \\
\hline
\end{tabular}

results confirmed the crystallinity of the NPs with a circular ring corresponding to the (111), (200), (220) and (311) phase for a faced-centred cubic structure. ${ }^{46}$

\section{Flowers}

Flower petals from plants are also some of the most useful reducing agents and stabilizing agents. Plumeria alba was able to synthesize extremely small sphericallike AuNPs in the size range of $12.2-19 \mathrm{~nm}^{86}$ The NPs produced by Moringa oleifera were even smaller, that is around 3-5 nm. Anand et al reported that this plant contained high levels of phytochemicals such as flavonoids, carotenoids, phenolic, sterols and amino acids. These constituents were believed to take part in the reduction process. ${ }^{87}$ Different species of roses also showed a reducing ability, such as Rosa damascene $^{88}$ and Rosa hybrida. ${ }^{47}$ A rapid reducing ability of roses is because of the ample sugars and proteins in the rose extract that ease the nucleation of smaller NPs. $^{47}$
Peels

Some research has been carried out using fruit peels, seed and the bark of plants. However, this has not been as popular as leaves which can be found abundantly. Waste products from the plants can be reused again by utilizing them in nanoparticle synthesis. The Garcinia mangostana fruit peel which is rich in xanthone was utilized to produce spherically shaped AuNPs with a size range from 27 to 37 $\mathrm{nm}$. The fruit peels were collected and air dried before being grinded into powder to produce peel crude extracts. The crude extract was able to cap the NPs by forming a protective layer around the NPs. This layer prevented them from aggregating. ${ }^{89}$

\section{Seeds}

Rajan et al demonstrated the synthesis of AuNPs by using the seed of true cardamom. The reaction was rapid and the NPs formed were $15.2 \mathrm{~nm}$ in size. ${ }^{90}$ Besides, the seed of fenugreek was utilized by Aromal and his co-workers for the production of AuNPs. The NPs were almost spherical 

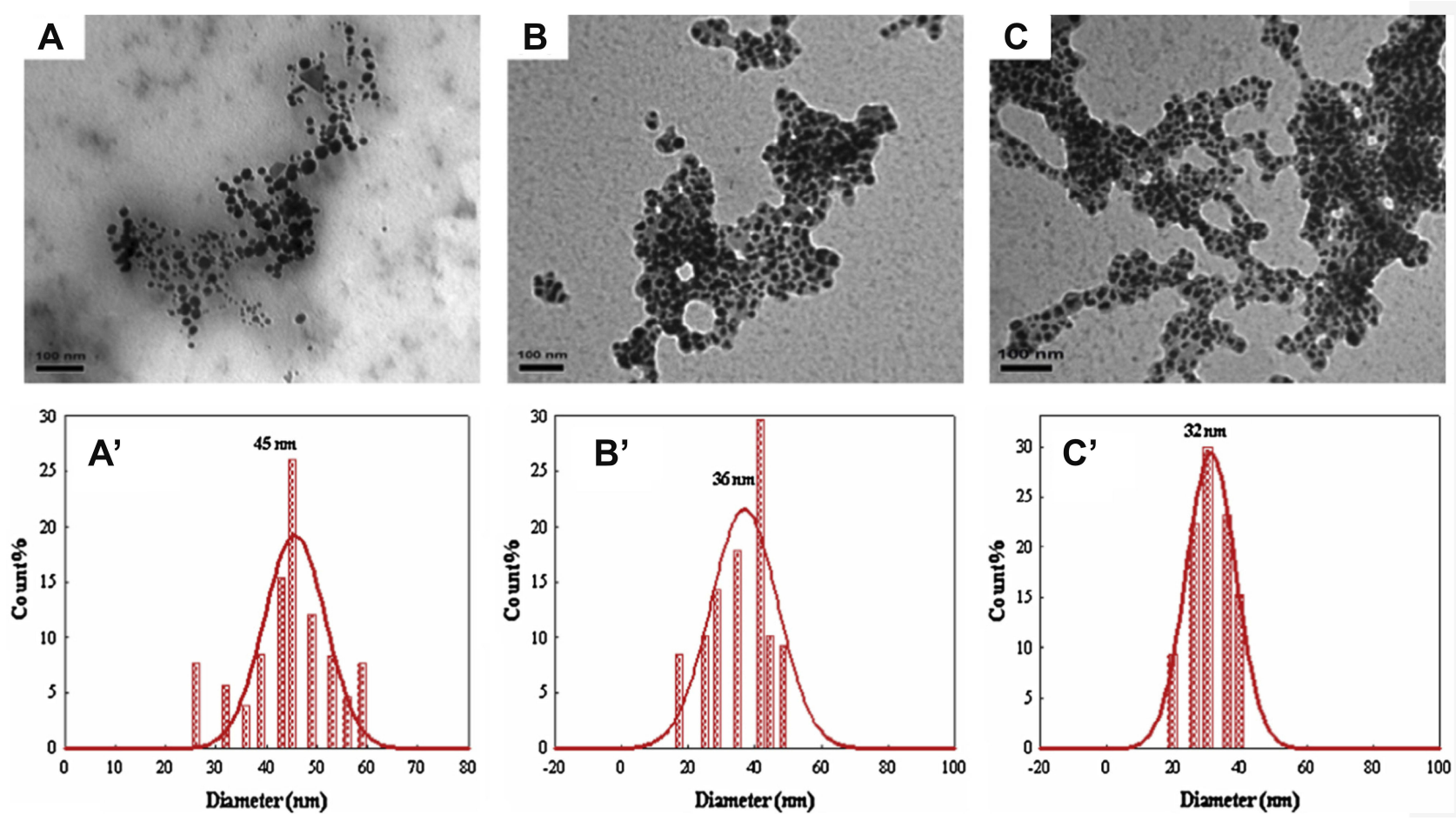

Figure 6 TEM micrographs of gold nanoparticles prepared with (A) 100, (B) 200 and (C) $400 \mathrm{IL}$ of a P. dactylifera extract. The corresponding histograms are represented by (A'), (B') and (C'). ${ }^{83}$ "Reprinted from Spectrochimica Acta Part A: Molecular and Biomolecular Spectroscopy, I2I, Mervat F. Zayed,Wael H. Eisa, Phoenix dactylifera L. leaf extract phytosynthesized gold nanoparticles; controlled synthesis and catalytic activity, 238-244, Copyright (20I4), with permission from Elsevier.".

in shape with a size of $15-25 \mathrm{~nm}$. The stability of the NPs synthesized at $\mathrm{pH} 6$ and 7 were stable for more than 3 months. This project also showed that an increase in $\mathrm{pH}$ will lead to a decrease in particle size which was probably due to the effect of $\mathrm{pH}$ towards the reducing groups in the extract, hence affecting the size of the NPs. ${ }^{91}$

\section{Others}

Some uncommon parts of plants have also been utilized to make AuNPs, such as essential oils, gum, gall and latex. One of the best examples is a project led by Alharbi et al where Arjun tree gum was used to reduce $\mathrm{HAuCl}_{4}$ into AuNPs. Color changes from light yellowish brown to reddish wine were observed within 5 mins. The formation of AuNPs was confirmed by obtaining a peak at $520 \mathrm{~nm}$ using UV-vis spectroscopy. ${ }^{92}$ Besides that, AuNPs can be synthesized using the latex of Ficus racemosa. The latex was first dissolved in double-distilled water to obtain a latex extract before adding the extract to a $\mathrm{HAuCl}_{4}$ solution. The mixture was kept under sunlight for around 2 hrs. ${ }^{93}$ The possible mechanism for the reduction of AuNPs was proposed as below:

$$
\begin{gathered}
\mathrm{AuCl}_{3}+2 e^{-} \stackrel{\text { reduction }}{\longrightarrow} \mathrm{AuCl}+2 \mathrm{Cl}^{-} \\
3 \mathrm{AuCl} \longrightarrow \mathrm{Au}^{0}+\mathrm{AuCl}_{3}
\end{gathered}
$$

\section{Other Green Materials}

\section{Fungi}

Fungi include molds, yeast, mushrooms and toadstools. This species has been recently exploited for the synthesis of NPs as compared to other microorganisms since they are capable of secreting plenty of proteins. ${ }^{94}$ Fungi are easier to culture in laboratories as well as in industries as compared to other microorganisms. The production of AuNPs by fungi requires a shorter time period, higher yields, and is high in ion concentration tolerance. ${ }^{95}$ Mostly, the fungi are cultured to obtain a mycelia free culture filtrate. The culture filtrate will mix and incubate with gold salts to obtain AuNPs.

Penicillium aculeatum is a type of mold able to produce spherical AuNPs with a size of $60 \mathrm{~nm}$. The stability of the NPs was around $-30 \mathrm{mV}$ suggesting that electrostatic repulsive forces were a major factor in its stability. This is due to the bonding of proteins on the surface of AuNPs. ${ }^{96}$ Manjunath et al used a marine endophytic 
fungus, Penicillium citrinum, to synthesize AuNPs. The NPs were irregular in shape with a size of 60 to $80 \mathrm{~nm}$. The research group suggested that polyphenol and certain proteins in the fungus were involved in the bioreduction of the AuNPs. ${ }^{94}$ Aspergillus sydowii was capable of producing AuNPs at a size of 8.7 to $15.6 \mathrm{~nm}$. At lower concentrations of $\mathrm{HAuCl}_{4}$, larger size particles were obtained, while higher concentrations supported the synthesis of smaller particles which was due to strain properties. ${ }^{97}$

However, the reaction time for some fungus is slow. A mitosporic fungus, Aspergillus sp, was able to produce NPs with a size of 4 to $29 \mathrm{~nm}$ but the reaction kinetics were slow. The reaction started only after $12 \mathrm{hrs}$ of incubation where the mixture color changed from light yellow to pink. $\mathrm{UV}$-vis spectroscopy recorded a peak at $532 \mathrm{~nm}$ after one day of incubation and the reaction ended at day 7 of incubation. ${ }^{98}$ Another species of mitosporic fungus, Aspergillum $s p$, required $2 \mathrm{hrs}$ of incubation before the reaction started. The reaction with $\mathrm{HAuCl}_{4}$ was completed after 7 days of incubation. Optimal conditions for the production of AuNPs were $\mathrm{pH}$ values of $7.0,100 \mathrm{mg} / \mathrm{mL}$ of biomass concentration, $3 \mathrm{mM}$ of $\mathrm{HAuCl}_{4}$ and using PBS as a buffer. The NPs synthesized possessed catalytic activity. ${ }^{95}$

Different kinds of mushrooms also have the ability to reduce AuNPs. Vetchinkina et al carried out a project with different kinds of mushrooms namely Lentinus edodes, Pleurotus ostreatus, Ganoderma lucidu and Grifola frondosa. Their experiment was used to recover gold, silver, selenium and silicon. This experiment determined that all of the fungi had the ability to synthesize AuNPs on the cell surface and culture medium. ${ }^{99}$ The reaction time for Changa mushroom is relatively short, around 30 mins. The NPs synthesized were mostly spherical, triangular, hexagonal and rod shaped. ${ }^{100}$ The shape of the NPs was greatly affected by the capping agents used because the capping agents control the size and shape of the NPs, for example, anisotropic growth was led by the non-specific binding nature on all AuNP exposed surfaces. ${ }^{101}$

\section{Bacteria}

Bacteria are prokaryotic microorganisms. Recently, researchers used different types of bacteria for the synthesis of AuNPs. The synthesis of NPs through a microbe can be classified into intracellular synthesis and extracellular synthesis according to the location of NP formation as shown in Figure 7. When the ions are transported into the microbial cell to form NPs in the presence of enzymes, it is indicated as an intracellular method, while the extracellular method is the formation of NPs by trapping the metal ions on the cell membrane with an enzyme. ${ }^{53}$ Figure 7 shows a simple picture illustrating the synthesis method of NPs using bacteria. However, utilizing bacteria as a green material is not economical. Bacteria culturing is a tedious process that takes time and extra precautions. The reaction time of the reduction process is also too slow, ranging from hours to days. These drawbacks have prevented the use of bacteria in nanoparticle production from reaching commercialization, nevertheless, some recent studies have highlighted that such NPs after synthesis are covered in proteins which target the bacteria that synthesized them, properties not possible with conventional NPs. ${ }^{102}$

Delftia sp. strain KCM-006 was able to produce spherically shaped AuNPs that were as small as $11.3 \mathrm{~nm}$. In this research, the experimental conditions were altered (such as $\mathrm{pH}$ and temperature). During the stirring process, the $\mathrm{pH}$ and temperature of the reaction environment was altered. It was found that the reaction time for the production of AuNPs was $7 \mathrm{hrs}$ at its optimal physiological conditions $\left(\mathrm{pH} 8\right.$ and $\left.45^{\circ} \mathrm{C}\right)$. These NPs were used for the transportation of resveratrol. ${ }^{103}$

Exopolysaccharide (EPS) produced by Bacillus megaterium MSBN04 was utilized for the synthesis of AuNPs by Sathiyanarayanan and his co-workers. Different conditions for bacteria culture were carried out and the environment for cell culture will affect EPS yield. This research found that the optimal condition for maximum EPS production was obtained at $30^{\circ} \mathrm{C}$ and at $\mathrm{pH} 7.5$ with the addition of $3-4 \%$ of $\mathrm{NaCl}$. With the increase of EPS concentration, a higher concentration of AuNPs was obtained. ${ }^{48}$

A highly salt tolerant proteobacterial, Halomonas salina, was capable of synthesizing spherical AuNPs 30 to $100 \mathrm{~nm}$ in diameter. When the temperature was low $\left(30^{\circ} \mathrm{C}\right)$, the optimal parameters were $\mathrm{pH} 9$ and a concentration of $100 \mathrm{ppm}$ of gold salt for the production of isotropic nanostructures. Under the same conditions, but at different $\mathrm{pH}$ values $(\mathrm{pH} 4)$, the NPs were anisotropic. This result showed that the fabrication of AuNPs was $\mathrm{pH}$ and temperature dependent. The NADH dependent enzyme may act as the reducing agent for this reaction. Functional groups in NADPH possess a positive charge at lower $\mathrm{pH}$ because of their high proton concentration. Thus, the NPs formed were less stable and tended to agglomerate. When the $\mathrm{pH}$ increased to the alkaline range, the reducing power of these groups increased and formed thermodynamically favorable structures. $^{21}$ 


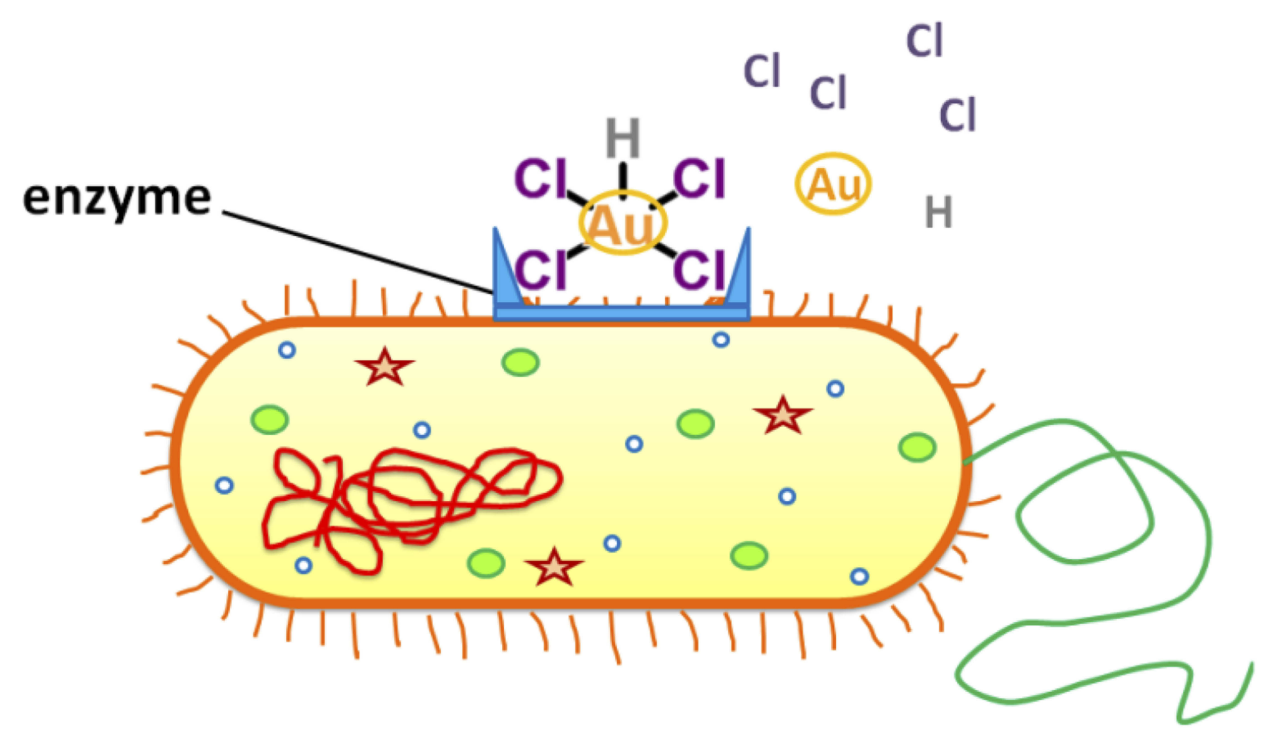

Extracellular Method

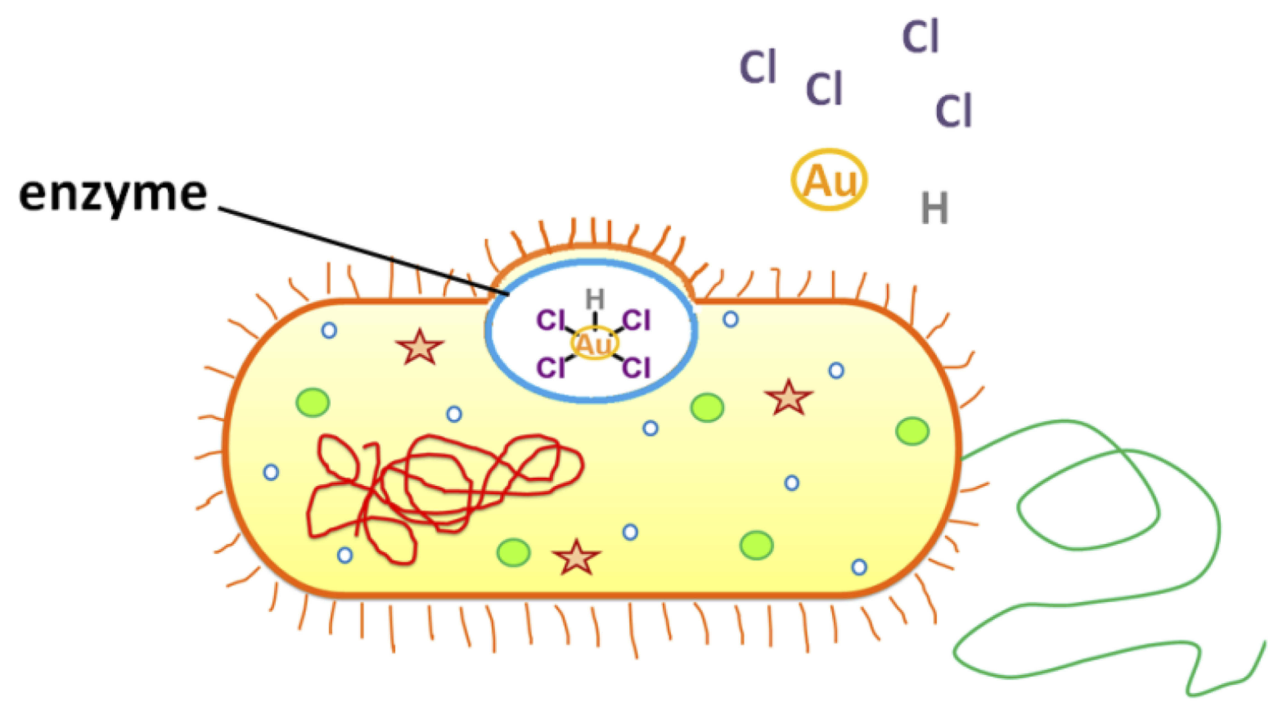

Intracellular Method

Figure 7 Gold nanoparticles can be synthesized via different approaches when using bacteria.

\section{Enzymes}

Researchers have suggested that enzymes maybe some of the best possible routes for the synthesis of NPs due to the many drawbacks of microbial bioreduction processes. They believe that microbes possess an ability to reduce AuNPs due to the presence of enzymes, proteins, carbohydrates and biomembranes. ${ }^{55}$ Also, enzymes are commercially available in pure form. This will ease the purification and production of the NPs. AuNPs can be produced via an enzymatic route of nisin peptides, a class-
Ia bacteriocin. It is a peptide that consists of 34 amino acids which can be obtained from Lactococcus lactis susbp. The NPs formed were spherical in shape with a size of $25 \mathrm{~nm}$. This result was confirmed by XRD analysis with JCPDF file No. 00-004-0784. ${ }^{104}$

A natural enzyme, diastase, was utilized to synthesize spherical $9.7 \mathrm{~nm}$ AuNPs. In this research, the quantity of enzymes varied. Smaller NPs were formed with an increasing volume of enzymes. When the colloid was prepared by diastase between $\mathrm{pH} 10$ and $\mathrm{pH}$ 4, one extra peak appeared 
between 650 and $800 \mathrm{~nm}$ suggesting the formation of an anisotropic structure. This is because the enzyme consists of freely exposed thiol groups which are believed to catalyse the synthesis of AuNPs. The decrease of the $\mathrm{pH}$ environment reduced the availability of thiol groups in anionic form. ${ }^{52}$ Hog pancreatic $\alpha$-amylase was able to reduce $\mathrm{HAuCl}_{4}$ to AuNPs too. However, the reaction was time consuming. It required $6 \mathrm{hrs}$ for NP formation at $37^{\circ} \mathrm{C}$ and the reaction ended only after 48 hrs. Rangnekar et al suggested that the enzyme has two free and exposed thiol groups (-SH) that accounted for its reducing ability. ${ }^{105}$

Many researchers have also suggested that the NADPH-dependent enzyme maybe one of the causes for the production of AuNPs during microbial synthesis. Narayanan et al proved that this may be possible as the NADPH-dependent enzyme from Sclerotium rolfsii has the ability to synthesize AuNPs within 10-15 mins. A control experiment with a heat denatured cell-free filtrate coenzyme NADPH was carried out. AuNPs were produced and it was suggested that the thermostable NADPH-dependent enzyme could be involved in the biosynthesis process. ${ }^{55}$

\section{Biopolymers}

Biopolymers are polymers that are synthesized by living organisms. They can be synthesized also through polymerization from renewable resources. They are bio-degradable polymers that consist of mostly organic compounds. Some examples of biopolymers are proteins, carbohydrates, DNA, RNA, lipids, peptides and polysaccharides. Biopolymers often consist of a variety of functional groups (such as carboxylic, amide I, amide II, aldehyde and ketone groups) that will ease the production of NPs. ${ }^{106-108}$

One of the most popular biopolymers that are involved as a reducing agent is chitosan. Chitosan is cellulose like linear polysaccharide that is produced by the deacetylation of chitin, a naturally occurring polymer. It is vastly found in marine invertebrates, insects, fungi and yeasts. ${ }^{109}$ Esther et al studied the difference in preparation methods towards the size and shape of the NPs. Two preparation methods were carried out. One was by adding chitosan into a boiling $\mathrm{HAuCl}_{4}$ solution while the other method was adding a $\mathrm{HAuCl}_{4}$ solution into hot boiling chitosan. When the $\mathrm{HAuCl}_{4}$ solution was added directly to the boiling chitosan solution, the nucleation rate was rapid and uniform. Hence, the NPs were spherical in shape and monodispersed. However, when the chitosan solution was poured into the hot $\mathrm{HAuCl}_{4}$ solution, the rate of nucleation was not as uniform because metal ions were absorbed on the matrix and slowly reduced to the nuclei.
Different shapes and larger size NPs were formed. ${ }^{110}$ Besides acting as a reducing agent, chitosan acted as a stabilizing agent in the presence of a plant based extract. Further, Saha et al carried out an experiment using a chitosan and black pepper extract. Better stability was obtained when both the chitosan and plant extract were used simultaneously. They proposed that chitosan mainly worked as a stabilizer through electrostatic interactions between the negatively charged AuNPs and positively charged polymeric network. ${ }^{111}$

Carbohydrate based materials can act as a reducing agent too. Honey mostly consists of fructose. It can act as a reducing agent when reacted with $\mathrm{HAuCl}_{4}$. $\mathrm{A}$ color change was observed after 3 hrs. The AuNPs produced were $15 \mathrm{~nm}$ in size and spherical in shape. ${ }^{108}$ Starch is a polymeric carbohydrate that mainly consists of glucose. It is capable to reduce gold salts to NPs under alkaline conditions. This is because under alkaline conditions, starch is degraded into shorter chains of carboxylic acid. Carboxylic acid consists of $-\mathrm{OH}$ groups that can reduce to AuNPs. Spherically shaped AuNPs with a size of 64 to 90 $\mathrm{nm}$ were formed under alkaline conditions. ${ }^{107}$

In the research of Geng et al, proteins can act as a reducing agent also. The research group used consensus sequence tetratricopeptide repeat (CTPR) proteins with a mild reducing agent, MOPS, to produce flower like AuNPs in the size of 23.6 to $46 \mathrm{~nm}$. The shape of the AuNPs changed from flower like to spherically shaped with an increase in the ratio of CTPR because the effect of the morpholine group in MOPS was empowered by CTPR that depleted the Au (iii) individual nucleation sites. CTPR proteins with different tandem repeating units were synthesized through recombinant bacteria expression technology. Both the morphology and LSPR absorbance can be adjusted by varying the ratio of reducing agent and protein length. ${ }^{106}$ Chen et al utilized a corn protein, $\alpha$-zein, to synthesize AuNPs. Increasing the concentration of $\alpha$-zein produced larger size NPs. Nanofibrils of $\alpha$-zein gave a better reducing ability as compared to normal $\alpha$-zein. This suggested that a smaller reducing agent possesses a better surface area for the reducing process. ${ }^{112}$

Bollela et al used quercetin to synthesize AuNPs. Quercetin is a plant polyphenol with flavonoid groups. The NPs synthesized in this experiment were spherical in shape. The reduction time of AuNPs was relatively fast at 30 mins. ${ }^{113}$ Hexagonal shaped AuNPs were produced using gallic acid, protocatechuic acid and isoflavone. The NPs synthesized using this method were stable under different $\mathrm{pH}$ values from slightly acidic to slightly 
alkaline. The NPs synthesized by protocatechuic acid were slightly larger than those from gallic acid. ${ }^{114}$

\section{Gold Nanoparticles for Biomedical Applications}

NPs contain small atoms or molecules that possess unique properties which vary from their bulk counterparts. Hence, they perform differently in terms of electronic, magnetic, optical, physical and chemical properties. ${ }^{15}$ Spherical AuNPs play an important role for the future of bio-nanotechnology development. They have large surface-to-volume ratios, good optoelectronic properties, excellent biocompatibility and low toxicity. AuNPs tend to interact with biomolecules (such as lipid, nucleic acid and proteins) due to their multiple surface compatibility properties. The immediate adsorption of biomolecules to AuNPs is called the "nanoparticleprotein corona". This interaction provides greater promise for clinical use. The effect of such a corona reduced the release of paclitaxel from nanocarriers and this effect is dependent on protein concentrations. ${ }^{115}$ Other than that, apolipoprotein is able to adsorb onto a NP surface for brain drug delivery. ${ }^{116}$ Although the toxicity of a nanoparticle is one of the concerns for its adaption for biomedical use, a few researches have even carried such studies to prove that they are safe to use at small concentrations. In the work of Mironava et al, $142 \mu \mathrm{g} / \mathrm{mL}$ of $13 \mathrm{~nm}$ AuNPs caused almost $40 \%$ of apoptosis of human fibroblast cells while $13 \mu \mathrm{g} / \mathrm{mL}$ of $45 \mathrm{~nm}$ AuNPs gave the same effect after 3 days of incubation. ${ }^{117}$ AuNPs have been shown to be non-toxic to normal L-cells when used at different amounts (from 1 to $100 \mu \mathrm{L}$ ). ${ }^{118}$ Another toxicity test was completed by Irama et al using radish. The root length and percent of seed germination was determined. Their research showed that AuNPs of sizes greater than $30 \mathrm{~nm}$ rarely entered the cell nucleus; hence, they may be more suitable for drug delivery. ${ }^{119}$ The toxicity of AuNPs was determined using in vivo animal models where it was found that toxicity was size dependent. Particles that were $10 \mathrm{~nm}$ in size were present in almost every tissue while larger particles were only detected in the liver, blood and spleen. ${ }^{120}$ Based on the work from Sadauskas et al, it was found that AuNPs gradually decreased and were removed from the circulation system to one fifth of their original amount after 6 months mainly by Kupffer cells. It was a long-term process. ${ }^{121}$ However, the damage caused by AuNPs was not permanent as cells were able to recover following AuNP removal. Near full recovery occurred for the cells after 14 days of AuNP removal (13nm and $45 \mathrm{~nm}$ in diameter). The number of vacuoles decreased which in turn allowed the cells to form normal actin fibers and increase their production as the cells divided and the concentration of AuNPs decreased. ${ }^{117}$ Still, more work is needed before AuNPs can be widely used clinically as current studies, especially involving humans, remain fragmented.

\section{Criteria for Biomedical Applications}

There are some critical criteria to follow so that AuNPs are useful in drug delivery systems. The first criterion is the size of the NPs. The efficacy of the NP depends highly on its size because its size controls its movement along the vasculature and in the body. The size of the NPs should be small enough to escape capture by macrophages in the liver and filtration by the kidney. Ideal particle sizes range from $10-100 \mathrm{~nm} .{ }^{122}$ The size the NPs also plays a large role in passive drug delivery systems where the enhanced permeability and retention (EPR) effect is utilized. The NPs should be at a certain size so that they can accumulate in the tumor and increase retention time in cancerous tissue for action on cancer cells. Tang et al found out that $50 \mathrm{~nm}$ drug-silica nanoconjugates showed the longest retention time in tumor tissue. This finding suggested that this size of nanoconjugates can penetrate deeper into tumors and cancer cells, are efficient in endocytosis, and work against primary and metastatic tumors. ${ }^{123}$

Secondly, the shape of the NP also influences drug delivery. The shape of NPs provides an impact on the accumulation and adhesion of NPs to blood vessel walls. ${ }^{124}$ Rod-like particles are difficult to internalize as compared to irregular shaped particles as shown by Gratton et al where HeLa cells took up nonspherical particles of hydrogels as large as $3 \mu \mathrm{m}$ readily via endocytosis. ${ }^{125}$ Spherical NPs are more preferable because they provide a smooth surface for coating and conjugation of ligands. Spherical NPs also have a higher surface-volume ratio where more reactive materials can be loaded for a better efficacy. ${ }^{126}$

Lastly, the efficiency of a delivery system is further increased by the conjugation of a targeting ligand. Different materials have been attached on the surface of NPs to improve their targeting ability, circulation and life span. Conjugation of hydrophilic surfaces on NPs has also allowed NPs to escape macrophage capture. Some examples of ligands are polyethylene glycol (PEG), folate receptor and aptamers. ${ }^{122}$ In research that tested surface charge and surface hydrophilicity, $25 \%$ of AuNPs conjugated with PEG and a galactose-targeting moiety accumulated in the liver after 20 mins and the liver only took up $2 \%$ of the NPs in this process. ${ }^{127}$ Folate targeted receptors bound to NPs formed a folate facilitated drug release mechanism. This approach ensured that the drug can be trafficked effectively across the endosomal membrane. Improved cytotoxicity was observed by the work of $\mathrm{Li}$ et al where doxorubicin was transported by a $\mathrm{N}$-(2-hydroxypropyl) methacrylamide 
copolymer into different tumor cells through the folate receptor. $^{128}$

\section{Gold Nanoparticles as Therapeutic Agents}

AuNPs can be employed as a drug for cancer treatment. The small size of NPs enables them to penetrate through cancer cells for targeted treatment. The presence of large vascular pores on the vessels that supply oxygen and nutrients to the tumor sites and inflamed tissues enables NPs to pass through easily and accumulate at these areas. ${ }^{127}$

Many researchers have shown that AuNPs have the ability to combat cancer cells successfully as shown in Table 3. AuNPs synthesized using Gymnema sylvestre, or commonly known as cowplant, exhibited cytotoxic effects towards Hep2 cells. Morphological changes were observed in Hep2 cells after treatment with AuNPs. Increases in the level of reactive oxygen species and nucleus changes were determined and suggested that the death of Hep2 cells was mediated by apoptosis. ${ }^{129}$ Another cervical cancer cell, HeLa cell line, reacted towards AuNPs as well. Morphological changes such as rounding, shrinking and granulation were observed. The activity of AuNPs was due to easy penetration of the NPs through the cell membrane. ${ }^{90}$

AuNPs have also reacted on other tumor cells, Ehrlich's Ascites Carcinoma, breast cancer cells and MCF-7 cells to name a few. Green tea polyphenols have been utilized to synthesize AuNPs. A comparison was made between green tea synthesized AuNPs and EGCG synthesized AuNPs. Both NPs were able to induce apoptosis in tumor cells while protecting normal hepatocytes from tumor cell damage. However, green synthesized AuNPs showed enhanced tumoricidal and hepatoprotective properties. ${ }^{130}$ AuNPs that were synthesised by Actinidia deliciosa showed $71 \%$ viability at their highest

Table 3 Cancer Cells That Have Been Targeted Successfully by Gold Nanoparticles

\begin{tabular}{|l|l|l|}
\hline Cancer Type & Cell Line & References \\
\hline Skin & BI6-FI0 & 45 \\
Breast & MCF-7, T47D & $45,130-132$ \\
Lung & A549 & $42,45,87,131$ \\
Gastric & NCL-N87 & 100 \\
Liver & Hep3B & 133 \\
Colon & HCT-II6 & 38 \\
Cervical & HeLa, Hep2 & $90,129,134$ \\
Bone & MG-63 & 133 \\
Tumor & Ehrlich ascites carcinoma, HNGC-2, & 130,133 \\
& MKN-28 & \\
\hline
\end{tabular}

concentration $(350 \mu \mathrm{g} / \mathrm{mL})$ when tested on HCT-116 cells using an MTT assay. The NPs exhibited a cytotoxic effect in a concentration dependent manner. ${ }^{38}$

\section{Gold Nanoparticles in Drug Delivery}

A wide range of molecules that have functional groups can bind easily with high affinity on the AuNPs surface. Capping agents surrounding the AuNPs can be displaced by other functioning thiols or adsorbed ligands through a ligand exchange reaction. External functional groups will displace the existing ligands on AuNPs under equilibrium. ${ }^{26}$ Sometimes, secondary coating molecules (such as PEG and BSA) are attached to provide a binding surface for specific cells. This is to minimize non-specific targeting on other tissues. AuNPs not only can carry small molecular drugs, but they are also capable of delivering large biomolecules (such as DNA, RNA, peptides and proteins). ${ }^{16}$

AuNPs have the ability to bind covalently or noncovalently with other materials through surface modification. Covalent conjugation stabilizes the conjugates for the purpose of imaging. Different interactions (such as specific binding affinity, electrostatic interactions and hydrophobic interactions) can attach molecules onto AuNPs non-covalently. These interactions produce modified AuNPs that are suitable for drug delivery because they require easy release of the drug for targeting purpose. Figure 8 shows a simple route of conjugating AuNPs with drugs for targeting cancer cells.

In the work of Devi et al, AuNPs were synthesised using Vitex negundo leaves as a reducing agent and Arabic gum as a stabilizing agent. Folic acid was loaded on the NPs afterwards to target lung cancer cells, specifically A549 cells. The presence of natural gum was proven to be a better approach for drug release, cytotoxicity and therapeutic efficacy. ${ }^{135}$ AuNPs were successfully conjugated with activated folic acid and chlorambucil molecules. These NPs showed high toxicity towards the cancer cell lines HeLa, RKO and A549 as compared to AuNPs and chlorambucil alone. The rate of drug release was the fastest at $\mathrm{pH} 5.4$ as compared to $\mathrm{pH} 6.7$ and 7.2. This research demonstrated a $\mathrm{pH}$ sensitive drug delivery system using AuNPs as a control where the amount of drug release was slowed in the blood stream $(\mathrm{pH} 7.2)$ and the release rate increased when it entered the tumor, suggesting that this drug-nanoparticle conjugate can be released to a major tumor environment (pH4.5-6.5). ${ }^{136}$

AuNPs were functionalized with a common anticancer drug, 5-Fluorouracil (5-Fu). The amount of drug required to obtain a $50 \%$ growth inhibition to MCF-7 was lower for the 


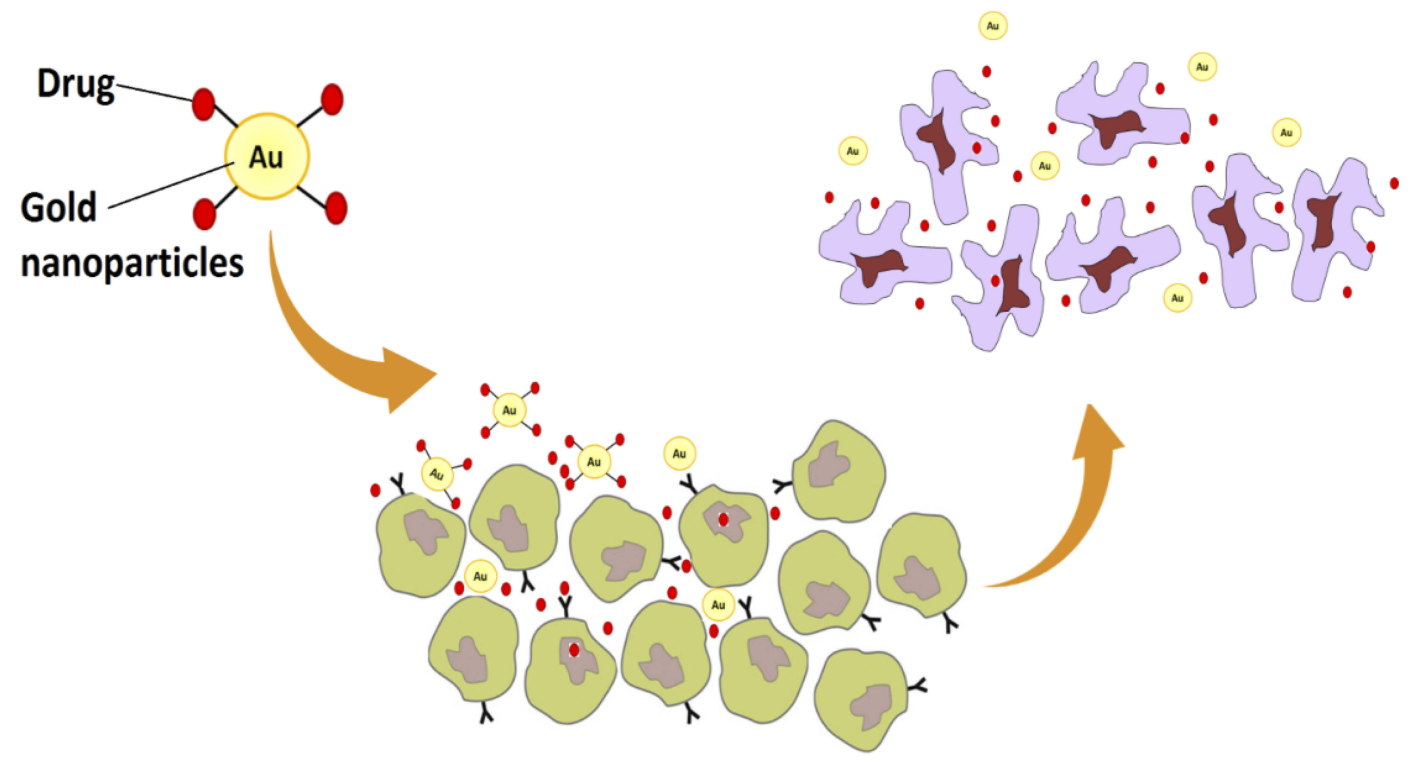

Figure 8 Schematic diagram showing the killing of cancer cells by gold nanoparticles.

drug loaded AuNPs as compared to free 5-Fu. This result showed that the cytotoxicity effect of the drug was enhanced after binding with AuNPs. ${ }^{137}$ The anticancer drug, doxorubicin, was also conjugated on AuNPs. When treated with 10 $\mu \mathrm{M}$ of AuNPs conjugated with doxorubicin, inhibition of cell proliferation increased from $50 \%$ to $60 \%$ as compared to free doxorubicin. ${ }^{44}$ When conjugated with the anticancer agent, resveratrol, cell viability and immunocytochemistry analysis showed that the drug loaded NPs were $65 \%$ more effective than resveratrol alone. The release was $95 \%$ under acidic conditions proving that this approach may be one of the strong alternatives for cancer targeting. ${ }^{103}$

\section{Gold Nanoparticles in Sensing}

AuNPs have been utilized in biosensing applications because they can be readily conjugated with recognition moieties, such as antibodies on the surface of biomolecules for their detection. AuNPs provide excellent sensitivity for determining cancerous cells, blood glucose levels, bacteria, viruses, biological toxins, pollutants, pathogens and biological molecules. ${ }^{26}$ Besides that, SPR of AuNPs leads to strong electromagnetic fields on the particle surface and consequently enhances radiative properties, such as absorption and scattering. Therefore, AuNPs possess easily tuneable and strong optical properties useful in optical imaging. Different kind of sensors can be constructed based on these special properties of AuNPs such as colorimetric, surface plasmon resonance, electrical, electrochemical, fluorescent and Bio-Barcode assay sensors. ${ }^{138}$
Red fluorescence gold nanoclusters were produced with diluted egg whites under alkaline conditions with the assistance of a microwave by Tian et al as shown in Figure 9A. Fluorescent signals of gold nanoclusters could be activated by living tumor cells (such as HepG2 and HeLa cells) while this did not affect normal cells. As time went on, the fluorescent ability became stronger. Within one hour, strong fluorescence could be seen as shown in Figure 9B. MTT assay results showed that the nanocluster had good biocompatibility with cells. Cell viability was more than $85 \%$ in the concentration range of $0-1.2 \mathrm{mg}$ per $\mathrm{mL}$ after $24 \mathrm{~h}$. This was an exciting result as it may work as a strategy for the preliminary recognition of tumor cells. ${ }^{139}$

Toxic substances can also be detected by using AuNPs. It was found that the fluorescence sensitivity of AuNPs towards aflatoxin B1 was enhanced up to 10-fold at picogram levels when conjugated with anti-aflatoxin antibodies. Aflatoxin is mainly produced by fungi and may cause disease and death towards living organisms. The detection of aflatoxins could be done more easily with the enhanced fluorescence properties of AuNPs. ${ }^{140}$ AuNPs were fabricated as a detector for painter's colic (lead poisoning). It is one of the most common toxic metals that can accumulate easily in plants and animals. Good results towards $\mathrm{Pb}^{2+}$ with a linear response range from 0.005 to $800 \mu \mathrm{ml}^{-1}$ were obtained. It was also highly selective towards $\mathrm{Pb}^{2+}$ even in the presence of a 100 fold concentration of other metal ions. ${ }^{17}$ A nitrobenzene sensor was also developed using AuNPs which showed exceptional selectivity in the presence of ions, phenolic and biologically coactive compounds too. The sensor was capable of reducing 

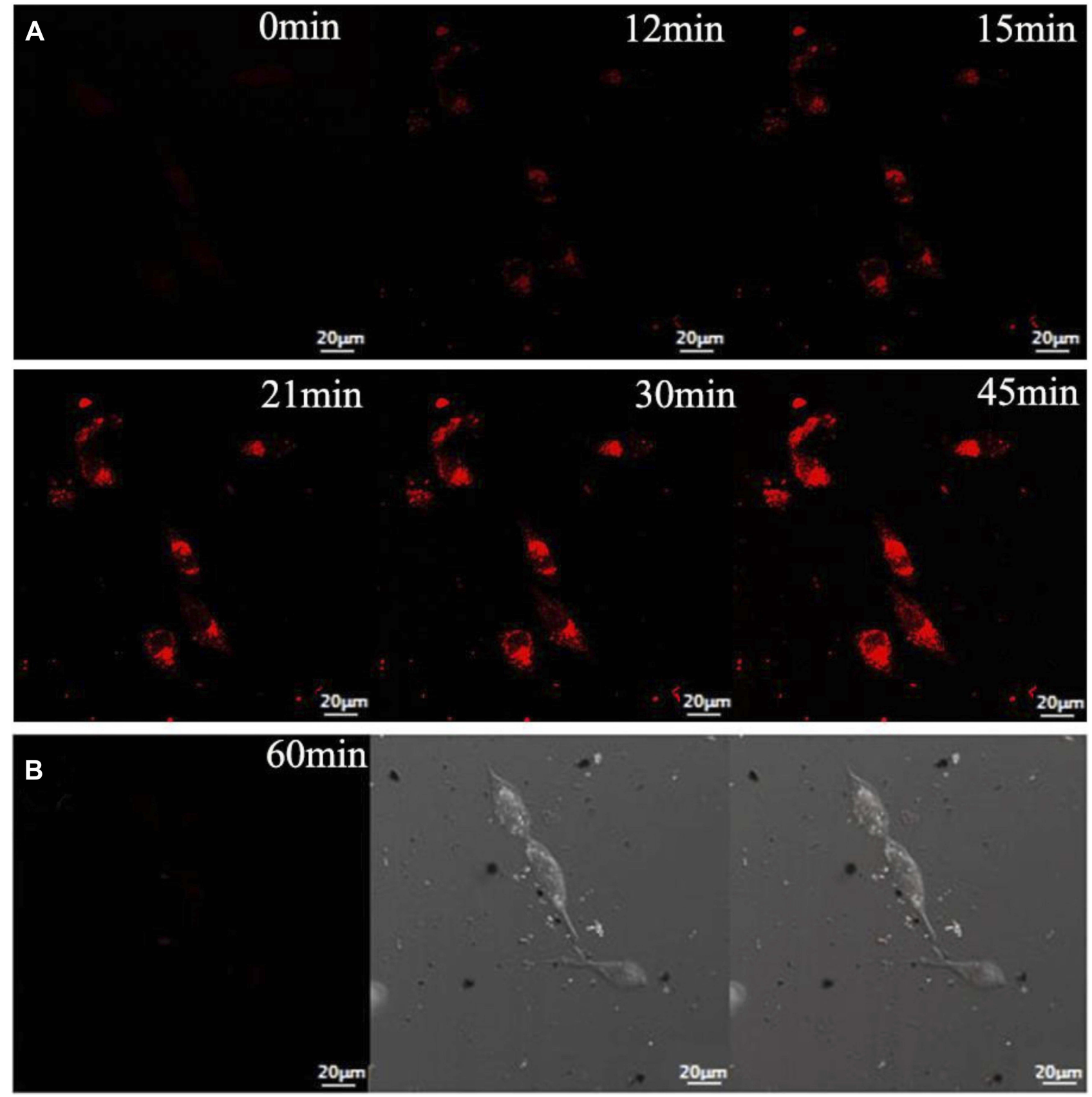

Figure 9 (A) Fluorescence confocal images of HepG2 cells after incubation with AuNCs@ew-Hg(II) for 0, 12, 15, 21,30 and 45 min. (B) Fluorescence confocal images of normal cells (HT22 cells) after incubation with AuNCs@ew-Hg(II) for I.0 h. The images in the left column show the fluorescence of the AuNCs@ew added to HT22 cells; the middle column shows the DIC images of cells in bright field; and the right column shows the merging of the two previous images. ${ }^{139}$ "Reprinted from Sensors and Actuators B: Chemical, 240, Lu Tian, Wenjing Zhao, Lin Li, Yaoli Tong, Guanlin Peng, Yingqi Li, Multi-talented applications for cell imaging, tumor cells recognition, patterning, staining and temperature sensing by using egg white-encapsulated gold nanoclusters, II4-124, Copyright (2017), with permission from Elsevier."

nitrobenzene and displayed a wide linear response from 0.1 to 600 $\mu \mathrm{M}^{43}$

A detector for vitamin $\mathrm{B}$ or thiamine was developed by Rao et al for the diagnosis of vitamins in blood and tissues to avoid illness especially neurological disorders. This study revealed that polyphenol capped AuNPs possess a good oxidation ability towards thiamine. They also generated thiochrome which is a fluorescent active compound. ${ }^{141} \mathrm{An}$ idea of measuring cysteine (which is a building block protein for our body and an essential metabolism biochemical) was proposed by Bahram et al. This research found that the change of the willow bark extract synthesized AuNPs SPR band was proportional to the cysteine concentration at a certain range. ${ }^{142}$ Besides that, the calorimetric detection of amino acids, 
proteins, nucleic acids and enzymes can be done by using AuNPs. A pectinase protected AuNPs cysteine sensor was synthesized by Qin et al where AuNPs were combined tightly with pectinase through a strong Au-S covalent bond and electrostatic binding. The range of this sensor was wide ( $4.85 \mathrm{nM}$ to $302 \mu \mathrm{M}$ and 3.25 to $10.3 \mathrm{mM}) .{ }^{143}$ A fluorometric and colorimetric dual-mode assay was used to determine adenosine triphosphate (ATP). This AuNP based detector possessed low detection limits and wide linear ranges without the introduction of an enzyme which provided a possible solution for biological molecules where aptamers were screened. ${ }^{144}$

Hemalatha et al found that dual acting oleyl chitosan functionalized with a AuNPs hybrid was useful in magnetic resonance imaging (MRI) and computed tomography (CT) imaging. AuNPs were used as a contrast agent and imaged using a clinical CT scanner where the images reflected the X-ray attenuation potency of the nanocomposite in a dose dependent manner. ${ }^{145}$

\section{Gold Nanoparticles as Antimicrobial Agents}

AuNPs are also capable of fighting bacteria, fungi and other pathogens. ${ }^{146-149}$ AuNPs exhibit antibacterial effects when they attach to the surface of a microbial cell wall because of their surface charge. The physicochemical surface modification between bacteria and NPs will release reactive oxygen species (ROS). This will cause protein denaturation, DNA destruction, mitochondrial disfunction and finally cell death. ${ }^{150}$ The antifungal activity of AuNPs may be due to binding of the NPs on the microbial surfaces through electrostatic interactions too. This reaction will inhibit the growth of fungi and generate ROS. The NPs will interrupt cell membrane permeability by attaching and collapsing intercellular communication. Moderate antibacterial and antifungal activity has been observed in thick cell wall microbials (such as gram positive bacteria) because the cell takes in the NPs through a transport system. The NPs will induce apoptosis by triggering mitochondrial oxidative stress, inhibiting adenosine triphosphate synthesis and interfere with intercellular signalling.

AuNPs synthesized using Mentha piperita or peppermint showed an antibacterial effect towards Gram negative pathogens (Escherichia coli) but not Gram positive Staphylococcus aureus. ${ }^{151}$ AuNPs that were produced by Euphorbia hirta inhibited the growth of some gram negative bacterial strains. Complete inhibition was observed when the concentration of AuNPs was $200 \mu \mathrm{g} / \mathrm{mL}$. An inhibition of $88 \%, 86 \%$ and $94 \%$ was calculated for Escherichia coli, Pseudomonas aeruginosa and Klebsiella pneumonia, respectively. The antibacterial effect was most probably due to the synergistic effect of the adherence of plant material onto the AuNPs. ${ }^{152}$ Two gram positive (Staphylococcus aureus and Bacillus subtilis) and three gram negative (Pseudomonas aeruginosa, Klebsiella pneumonia and Escherichia coli) bacteria were used to determine the antibacterial property of AuNPs produced by using the seed extract of a cassod tree. K. pneumoniae were highly sensitive towards AuNPs with a $21 \mathrm{~mm}$ inhibition zone. ${ }^{153}$ AuNPs were effective towards Salmonella typhi and Enterococcus faecalis too. ${ }^{154}$

Fungal tests using Candida tropicalis and Candida albicans were carried out by using AuNPs. The NPs were synthesized by a Terminalia bellirica fruit extract. The inhibition zone was $16 \mathrm{~mm}$ and $14 \mathrm{~mm}$ for Candida tropicalis and Candida albicans, respectively. ${ }^{155} 14$ species of pathogens were tested in the project by Karthika and his co-workers. The pathogens were gram positive (Bacillus subtilis, Staphylococcus aureus, and Streptococcus pneumoniae), gram negative (Escherichia coli, Proteus vulgaris, Shigella dysenteriae, Klebsiella pneumoniae, and Pseudomonas aeruginosa) and fungi (Trichoderma viridae, Fusarium solani, Aspergillus niger, Nigrospora oryzae, Aspergillus fumicatus, and Candida albicans). ${ }^{156}$ A well diffusion method was carried out between the fungal strains Alternaria solani, Aspergillus niger and Aspergillus flavus and Pistacia integerrima gall extract synthesized AuNPs. The NPs possessed moderate antifungal activity as compared to the control. ${ }^{157}$ AuNPs synthesized by banana peels displayed antifungal properties towards a pathogenic strain of Candida albicans (BX and BH). ${ }^{158}$

\section{Future Prospectives and Conclusions}

The production of AuNPs is facile and simple when it comes to green synthesis. The reaction can be done under mild environments without the elevation of temperature and pressure. The reaction rate is dependent on the green reducing agent. Normally, a plant based reducing agent gives the fastest reaction, ranging from minutes to hours as compared to other green materials. Despite the advantages achieved by green synthesis, more work is needed to commercialize and scale up the production of AuNPs. Unlike physical and chemical synthesis, there are still many unknown factors preventing this method to earn its proper place in medicine. Different research has been carried out using green materials because of the presence 
Table 4 The Shape of Gold Nanoparticles and their Applications

\begin{tabular}{|l|l|l|}
\hline Shape of AuNPs & Applications & References \\
\hline Spherical & Photothermal therapy, drug delivery and cancer therapy \\
Plate particles & Electrochemical sensor & I59-I6I \\
Hollow particles & CT imaging cancer therapy \\
Triangular & Photodynamic and photothermal therapy, immunosensor and catalyst \\
Hexagonal & Catalyst & I62 \\
Nanorod & Marker and biosensor \\
Nanoflowers & Biosensor for diseases and removal of dye or heavy metal \\
Network dendrite & Antifungal and antibacterial agent \\
\hline
\end{tabular}

of organic compounds and functional groups in the materials. However, the mechanism of production is unclear. More detailed research should focus on the properties of the reducing agents. Determination of the main reducing components or organic groups should be carried out so that a precise and repeatable method can be established. The mechanism and bonding of the reaction should be studied as well so as to provide information for the utilization of the NPs. Details of the formation of NPs need to be mastered before adapting them to different areas.

AuNPs can be used in different areas such as medicine, technology, chemistry and industry. More and more studies need to be carried out to determine the prospective uses of AuNPs in the medicinal area because of their unique properties. AuNPs are capable of emitting fluorescence. This property can be used as a marker for diseases. Their multisurface functionality makes them possible candidates to transport drugs for a targeted treatment. Although many researchers have proven that AuNPs are non-toxic, a detailed toxicity test should be carried out to determine the safety of NPs when it comes to their application and use. Tests should be carried out to determine the duration of NPs in our body before being discharged. It is also important to check the residual power of the NPs in our body and effects due to this. The dosage of the AuNPs should be tested precisely so that a suitable amount of drugs can be given to patients effectively. Research also should start to focus on in vivo studies so that the possibility of AuNPs as a drug or carrier can be achieved in the near future.

In conclusion, different shapes and sizes of AuNPs can be formed using different types of green materials. Unique properties of AuNPs enable them to be used in different applications as shown in Table 4. The green synthesis method is one of the least toxic methods towards the environment and living organisms and can even produce AuNPs more effective than those made through conventional chemical or physical methods. Such a green synthesis method is believed to be one of the brightest developments in recent years.

\section{Acknowledgments}

Gratitude is given to the members of the Chemical Energy Conversions and Applications (ChECA) Research Laboratory, Department of Environmental Engineering, Green Technology, Malaysia-Japan International Institute of Technology, Universiti Teknologi Malaysia Kuala Lumpur and the Department of Chemical Engineering, 313 Snell Engineering Center, Northeastern University, Boston, MA, USA.

\section{Funding}

This research was funded by the Ministry of Education, grant number 05547.

\section{Disclosure}

The authors report no conflicts of interest in this work.

\section{References}

1. Abou El-Nour KMM, Eftaiha AA, Al-Warthan A, Ammar RAA. Synthesis and applications of silver nanoparticles. Arab J Chem. 2010;3(3):135-140. doi:10.1016/j.arabjc.2010.04.008

2. Xie T, Zhang L, Wang Y, Wang Y, Wang X. Graphene-based supercapacitors as flexible wearable sensor for monitoring pulse-beat. Ceram Int. 2019;45(2):2516-2520. doi:10.1016/j. ceramint.2018.10.181

3. Sadjadi S, Malmir M, Heravi MM. A novel magnetic heterogeneous catalyst based on decoration of halloysite with ionic liquid-containing dendrimer. Appl Clay Sci. 2019;168:184-195. doi:10.1016/j. clay.2018.11.012

4. Shrivastava S, Jadon N, Jain R. Next-generation polymer nanocomposite-based electrochemical sensors and biosensors: a review. TrAC Trends Anal Chem. 2016;82:55-67. doi:10.1016/j. trac.2016.04.005

5. Jahangirian H, Lemraski EG, Rafiee-Moghaddam R, Webster TJ. A review of using green chemistry methods for biomaterials in tissue engineering. Int J Nanomed. 2018;13:5953. doi:10.2147/IJN 
6. Gaharwar AK, Peppas NA, Khademhosseini A. Nanocomposite hydrogels for biomedical applications. Biotechnol Bioeng. 2014;111(3):441-453. doi:10.1002/bit.25160

7. Thakkar KN, Mhatre SS, Parikh RY. Biological synthesis of metallic nanoparticles. Nanomed Nanotechnol Biol Med. 2010;6 (2):257-262. doi:10.1016/j.nano.2009.07.002

8. Alam MN, Das S, Batuta S, et al. Murraya koenegii spreng. leaf extract: an efficient green multifunctional agent for the controlled synthesis of Au nanoparticles. ACS Sustain Chem Eng. 2014;2 (4):652-664. doi:10.1021/sc400562w

9. Sasidharan S, Raj S, Sonawane S, Pinjari D, Pandit AB, Saudagar P. Nanomaterial synthesis: chemical and biological route and applications. In: Nanomaterials Synthesis. Elsevier; 2019:27-51.

10. Deepak P, Amutha V, Kamaraj C, Balasubramani G, Aiswarya D, Perumal P. Chemical and green synthesis of nanoparticles and their efficacy on cancer cells. In: Green Synthesis, Characterization and Applications of Nanoparticles. Elsevier; 2019:369-387.

11. Wang S, Huang $P$, Chen $X$. Hierarchical targeting strategy for enhanced tumor tissue accumulation/retention and cellular internalization. Adv Mater. 2016;28(34):7340-7364. doi:10.1002/ adma. 201601498

12. Jahangirian H, Lemraski EG, Webster TJ, Rafiee-Moghaddam R, Abdollahi Y. A review of drug delivery systems based on nanotechnology and green chemistry: green nanomedicine. Int J Nanomed. 2017;12:2957. doi:10.2147/IJN

13. Fan W, Yung B, Huang P, Chen X. Nanotechnology for multimodal synergistic cancer therapy. Chem Rev. 2017;117 (22):13566-13638. doi:10.1021/acs.chemrev.7b00258

14. Jiang D, Ni D, Rosenkrans ZT, Huang P, Yan X, Cai W. Nanozyme: new horizons for responsive biomedical applications. Chem Soc Rev. 2019;48(14):3683-3704.

15. Rad AG, Abbasi H, Afzali MH. Gold nanoparticles: synthesising, characterizing and reviewing novel application in recent years. Phys Procedia. 2011;22:203-208. doi:10.1016/j.phpro.2011.11.032

16. Ghosh P, Han G, De M, Kim CK, Rotello VM. Gold nanoparticles in delivery applications. Adv Drug Deliv Rev. 2008;60 (11):1307-1315. doi:10.1016/j.addr.2008.03.016

17. Karuppiah C, Palanisamy S, Chen S-M, Emmanuel R, Muthupandi K, Prakash P. Green synthesis of gold nanoparticles and its application for the trace level determination of painter's colic. RSC Adv. 2015;5(21):16284-16291. doi:10.1039/ C4RA14988B

18. Shahzad SA, Sajid MA, Khan ZA, Canseco-Gonzalez D. Gold catalysis in organic transformations: a review. Synth Commun. 2017;47(8):735-755. doi:10.1080/00397911.2017.1280508

19. Islam NU, Jalil K, Shahid M, et al. Green synthesis and biological activities of gold nanoparticles functionalized with Salix alba. Arab J Chem. 2015.

20. Abbasi T, Anuradha J, Ganaie SU, Abbasi SA. Biomimetic synthesis of nanoparticles using aqueous extracts of plants (botanical species). J Nano Res. 2015;31:138-202. doi:10.4028/www.scientific.net/JNanoR.31

21. Shah R, Oza G, Pandey S, Sharon M. Biogenic fabrication of gold nanoparticles using halomonas salina. J Microbiol Biotechnol. 2012;2(4):485-492.

22. Siddiqi KS, Husen A. Recent advances in plant-mediated engineered gold nanoparticles and their application in biological system. J Trace Elem Med Biol. 2016.

23. Teimuri-Mofrad R, Hadi R, Tahmasebi B, Farhoudian S, Mehravar M, Nasiri R. Green synthesis of gold nanoparticles using plant extract: mini-review. Nanochem Res. 2017;2(1):8-19.

24. Bogireddy N, Pal U, Gomez LM, Agarwal V. Size controlled green synthesis of gold nanoparticles using coffea arabica seed extract and their catalytic performance in 4-nitrophenol reduction. RSC Adv. 2018;8(44):24819-24826. doi:10.1039/C8RA04332A
25. Dash SS, Bag BG, Hota P. Lantana camara linn leaf extract mediated green synthesis of gold nanoparticles and study of its catalytic activity. Appl Nanosci. 2014;5(3):343-350. doi:10.1007/ s13204-014-0323-4

26. Yeh Y-C, Creran B, Rotello VM. Gold nanoparticles: preparation, properties, and applications in bionanotechnology. Nanoscale. 2012;4(6):1871-1880. doi:10.1039/C1NR11188D

27. Lee KX, Shameli K, Miyake M, et al. Gold nanoparticles biosynthesis: a simple route for control size using waste peel extract. IEEE Trans Nanotechnol. 2017;16(6):954-957. doi:10.1109/ TNANO.2017.2728600

28. Kumar B, Smita K, Cumbal L, Debut A. Extracellular biofabrication of gold nanoparticles by using lantana camara berry extract. Inorg Nano-Metal Chem. 2017;47(1):138-142. doi:10.1080/ 15533174.2016.1157817

29. Huang X, El-Sayed MA. Gold nanoparticles: optical properties and implementations in cancer diagnosis and photothermal therapy. $J$ Adv Res. 2010;1(1):13-28. doi:10.1016/j. jare.2010.02.002

30. Singh P, Pandit S, Garnæs J, et al. Green synthesis of gold and silver nanoparticles from cannabis sativa (industrial hemp) and their capacity for biofilm inhibition. Int $J$ Nanomed. 2018;13:3571. doi:10.2147/IJN.S157958

31. Kim H-S, Seo YS, Kim K, Han JW, Park Y, Cho S. Concentration effect of reducing agents on green synthesis of gold nanoparticles: size, morphology, and growth mechanism. Nanoscale Res Lett. 2016;11(1):230. doi:10.1186/s11671-016-1393-x

32. Yuan C-G, Huo C, Yu S, Gui B. Biosynthesis of gold nanoparticles using capsicum annuum var. grossum pulp extract and its catalytic activity. Physica E. 2017;85:19-26. doi:10.1016/j. physe.2016.08.010

33. Anuradha J, Abbasi T, Abbasi S. An eco-friendly method of synthesizing gold nanoparticles using an otherwise worthless weed pistia (pistia stratiotes L.). J Adv Res. 2015;6(5):711-720. doi:10.1016/j.jare.2014.03.006

34. González-Ballesteros N, Rodríguez-González J, RodríguezArgüelles M. Harnessing the wine dregs: an approach towards a more sustainable synthesis of gold and silver nanoparticles. J Photochem Photobiol B. 2018;178:302-309. doi:10.1016/j. jphotobiol.2017.11.025

35. Nadagouda MN, Iyanna $\mathrm{N}$, Lalley J, Han C, Dionysiou DD, Varma RS. Synthesis of silver and gold nanoparticles using antioxidants from blackberry, blueberry, pomegranate, and turmeric extracts. ACS Sustain Chem Eng. 2014;2(7):1717-1723.

36. Gan PP, Ng SH, Huang Y, Li SFY. Green synthesis of gold nanoparticles using palm oil mill effluent (POME): a low-cost and eco-friendly viable approach. Bioresour Technol. 2012;113:132-135. doi:10.1016/j.biortech.2012.01.015

37. Sundararajan B, Kumari BR. Novel synthesis of gold nanoparticles using artemisia vulgaris L. leaf extract and their efficacy of larvicidal activity against dengue fever vector aedes aegypti L. $J$ Trace Elem Med Biol. 2017;43:187-196. doi:10.1016/j. jtemb.2017.03.008

38. Naraginti S, Li Y. Preliminary investigation of catalytic, antioxidant, anticancer and bactericidal activity of green synthesized silver and gold nanoparticles using actinidia deliciosa. J Photochem Photobiol B. 2017;170:225-234. doi:10.1016/j. jphotobiol.2017.03.023

39. Song JY, Jang H-K, Kim BS. Biological synthesis of gold nanoparticles using magnolia kobus and diopyros kaki leaf extracts. Process Biochem. 2009;44(10):1133-1138. doi:10.1016/j. procbio.2009.06.005

40. Elavazhagan T, Arunachalam KD. Memecylon edule leaf extract mediated green synthesis of silver and gold nanoparticles. Int J Nanomedicine. 2011;6:1265-1278. doi:10.2147/IJN.S18347 
41. Ho C-T. Phenolic Compounds in Food: An Overview. Phenolic Compounds in Food and Their Effects on Health I. Washington: ACS Publications; 1992:2-7.

42. Vijayakumar S, Vaseeharan B, Malaikozhundan B, et al. Therapeutic effects of gold nanoparticles synthesized using musa paradisiaca peel extract against multiple antibiotic resistant enterococcus faecalis biofilms and human lung cancer cells (A549). Microb Pathog. 2017;102:173-183. doi:10.1016/j. micpath.2016.11.029

43. Emmanuel R, Karuppiah C, Chen S-M, Palanisamy S, Padmavathy S, Prakash P. Green synthesis of gold nanoparticles for trace level detection of a hazardous pollutant (nitrobenzene) causing methemoglobinaemia. $J$ Hazard Mater. 2014;279:117-124. doi:10.1016/j.jhazmat.2014.06.066

44. Mukherjee S, Sushma V, Patra S, et al. Green chemistry approach for the synthesis and stabilization of biocompatible gold nanoparticles and their potential applications in cancer therapy. Nanotechnology. 2012;23(45):455103. doi:10.1088/0957-4484/23/45/455103

45. Patra S, Mukherjee S, Barui AK, Ganguly A, Sreedhar B, Patra CR. Green synthesis, characterization of gold and silver nanoparticles and their potential application for cancer therapeutics. Mater Sci Eng C-Mater Biol Appl. 2015;53:298-309. doi:10.1016/j.msec.2015.04.048

46. Mahakham W, Theerakulpisut P, Maensiri S, Phumying S, Sarmah AK. Environmentally benign synthesis of phytochemicals-capped gold nanoparticles as nanopriming agent for promoting maize seed germination. Sci Total Environ. 2016;573:1089-1102. doi:10.1016/j.scitotenv.2016.08.120

47. Noruzi M, Zare D, Khoshnevisan K, Davoodi D. Rapid green synthesis of gold nanoparticles using rosa hybrida petal extract at room temperature. Spectroc Acta Pt A-Molec Biomolec Spectr. 2011;79(5):1461-1465. doi:10.1016/j.saa.2011.05.001

48. Sathiyanarayanan G, Vignesh V, Saibaba G, et al. Synthesis of carbohydrate polymer encrusted gold nanoparticles using bacterial exopolysaccharide: a novel and greener approach. RSC Adv. 2014;4(43):22817-22827. doi:10.1039/C4RA01428F

49. Mewada A, Oza G, Pandey S, Sharon M. Extracellular synthesis of gold nanoparticles using pseudomonas denitrificans and comprehending its stability. J Microbiol Biotechnol. 2012;2(4):493-499.

50. Wadhwani SA, Shedbalkar UU, Singh R, Karve MS, Chopade BA. Novel polyhedral gold nanoparticles: green synthesis, optimization and characterization by environmental isolate of acinetobacter sp. SW30. World J Microbiol Biotechnol. 2014;30(10):2723-2731. doi:10.1007/s11274-014-1696-y

51. Dhanasekar N, Rahul G, Narayanan K, Raman G, Sakthivel N. Green chemistry approach for the synthesis of gold nanoparticles using the fungus alternaria sp. J Microbiol Biotechnol. 2015;25 (7):1129-1135. doi:10.4014/jmb.1410.10036

52. Babu Maddinedi S, Mandal BK, Ranjan S, Dasgupta N. Diastase assisted green synthesis of size-controllable gold nanoparticles. RSC Adv. 2015;5(34):26727-26733. doi:10.1039/C5RA03117F

53. Li X, Xu H, Chen Z-S, Chen G. Biosynthesis of nanoparticles by microorganisms and their applications. $J$ Nanomater. 2011;2011:1-8. doi:10.1155/2011/910539

54. Narayanan KB, Park HH, Han SS. Synthesis and characterization of biomatrixed-gold nanoparticles by the mushroom flammulina velutipes and its heterogeneous catalytic potential. Chemosphere. 2015;141:169-175. doi:10.1016/j.chemosphere.2015.06.101

55. Narayanan KB, Sakthivel N. Facile green synthesis of gold nanostructures by NADPH-dependent enzyme from the extract of sclerotium rolfsii. Colloid Surf A-Physicochem Eng Asp. 2011;380(1):156-161. doi:10.1016/j.colsurfa.2011.02.042

56. Singh J, Kaur G, Kaur P, Bajaj R, Rawat M. A review on grenn synthesis and characteriszation of silver nanoparticles and their applications: a green nanoworld. J Pharm Pharm Sci. 2016;5 (7):730-762.
57. Iravani HK, Mirmohammadi S. B Zolfaghari S. Synthesis of silver nanoparticles: chemical, physical and biological methods. Res Pharm Sci. 2014;9(6):385-406.

58. Bogireddy NKR, Anand KKH, Mandal BK. Gold nanoparticlessynthesis by sterculia acuminata extract and its catalytic efficiency in alleviating different organic dyes. $J$ Mol Liq. 2015;211:868-875. doi:10.1016/j.molliq.2015.07.027

59. Patil MP, Kim G-D. Eco-friendly approach for nanoparticles synthesis and mechanism behind antibacterial activity of silver and anticancer activity of gold nanoparticles. Appl Microbiol Biotechnol. 2017;101(1):79-92. doi:10.1007/s00253-016-8012-8

60. Zadernowski R, Czaplicki S, Naczk M. Phenolic acid profiles of mangosteen fruits (garcinia mangostana). Food Chem. 2009;112 (3):685-689. doi:10.1016/j.foodchem.2008.06.030

61. Gopinath K, Venkatesh K, Ilangovan R, Sankaranarayanan K, Arumugam A. Green synthesis of gold nanoparticles from leaf extract of terminalia arjuna, for the enhanced mitotic cell division and pollen germination activity. Ind Crops Prod. 2013;50:737-742. doi:10.1016/j.indcrop.2013.08.060

62. Arunachalam KD, Annamalai SK, Hari S. One-step green synthesis and characterization of leaf extract-mediated biocompatible silver and gold nanoparticles from memecylon umbellatum. Int J Nanomed. 2013;8:1307. doi:10.2147/IJN

63. Khalil MM, Ismail EH, El-Magdoub F. Biosynthesis of Au nanoparticles using olive leaf extract: 1 st nano updates. Arab J Chem. 2012;5(4):431-437. doi:10.1016/j.arabjc.2010.11.011

64. Kumar VG, Gokavarapu SD, Rajeswari A, et al. Facile green synthesis of gold nanoparticles using leaf extract of antidiabetic potent cassia auriculata. Colloid Surf B-Biointerfaces. 2011;87 (1):159-163. doi:10.1016/j.colsurfb.2011.05.016

65. Philip D. Rapid green synthesis of spherical gold nanoparticles using mangifera indica leaf. Spectroc Acta Pt A-Molec Biomolec Spectr. 2010;77(4):807-810. doi:10.1016/j.saa.2010.08.008

66. Yu J, Xu D, Guan HN, Wang C, Huang LK. Facile one-step green synthesis of gold nanoparticles using citrus maxima aqueous extracts and its catalytic activity. Mater Lett. 2016;166:110-112. doi:10.1016/j.matlet.2015.12.031

67. Sujitha MV, Kannan S. Green synthesis of gold nanoparticles using Citrus Fruits (Citrus Limon, Citrus Reticulata And Citrus Sinensis) aqueous extract and its characterization. Spectroc Acta Pt A-Molec Biomolec Spectr. 2013;102:15-23. doi:10.1016/j. saa.2012.09.042

68. Ghodake G, Lee DS. Green synthesis of gold nanostructures using pear extract as effective reducing and coordinating agent. Korean J Chem Eng. 2011;28(12):2329-2335. doi:10.1007/ s11814-011-0115-4

69. Lv J, Yi Y, Wu G, Liu W. Gold nanotriangles: green synthesis and PDT \& PTT effect. Mater Lett. 2017;187:148-150. doi:10.1016/j. matlet.2016.10.087

70. Ganesan R, Prabu HG. Synthesis of gold nanoparticles using herbal acorus calamus rhizome extract and coating on cotton fabric for antibacterial and UV blocking applications. Arab J Chem. 2015. doi:10.1016/j.arabjc.2014.12.017

71. Velmurugan P, Anbalagan K, Manosathyadevan M, et al. Green synthesis of silver and gold nanoparticles using zingiber officinale root extract and antibacterial activity of silver nanoparticles against food pathogens. Bioprocess Biosyst Eng. 2014;37 (10):1935-1943. doi:10.1007/s00449-014-1169-6

72. Leonard K, Ahmmad B, Okamura H, Kurawaki J. In situ green synthesis of biocompatible ginseng capped gold nanoparticles with remarkable stability. Colloid Surf B-Biointerfaces. 2011;82 (2):391-396. doi:10.1016/j.colsurfb.2010.09.020

73. Nagajyothi P, Lee SE, An M, Lee KD. Green synthesis of silver and gold nanoparticles using lonicera japonica flower extract. Bull Korean Chem Soc. 2012;33(8):2609-2612. doi:10.5012/ bkcs.2012.33.8.2609 
74. Das RK, Gogoi N, Bora U. Green synthesis of gold nanoparticles using nyctanthes arbortristis flower extract. Bioprocess Biosyst Eng. 2011;34(5):615-619. doi:10.1007/s00449-010-0510-y

75. Yang N, WeiHong L, Hao L. Biosynthesis of Au nanoparticles using agricultural waste mango peel extract and its in vitro cytotoxic effect on two normal cells. Mater Lett. 2014;134:67-70. doi:10.1016/j.matlet.2014.07.025

76. Kumar KM, Mandal BK, Kumar HAK, Maddinedi SB. Green synthesis of size controllable gold nanoparticles. Spectroc Acta Pt A-Molec Biomolec Spectr. 2013;116:539-545. doi:10.1016/j. saa.2013.07.077

77. Fazal S, Jayasree A, Sasidharan S, Koyakutty M, Nair SV, Menon D. Green synthesis of anisotropic gold nanoparticles for photothermal therapy of cancer. ACS Appl Mater Interfaces. 2014;6(11):8080-8089. doi:10.1021/am500302t

78. Jayaseelan C, Ramkumar R, Rahuman AA, Perumal P. Green synthesis of gold nanoparticles using seed aqueous extract of abelmoschus esculentus and its antifungal activity. Ind Crops Prod. 2013;45:423-429. doi:10.1016/j.indcrop.2012.12.019

79. Paul B, Bhuyan B, Purkayastha DD, Vadivel S, Dhar SS. One-pot green synthesis of gold nanoparticles and studies of their anticoagulative and photocatalytic activities. Mater Lett. 2016;185:143-147. doi:10.1016/j.matlet.2016.08.121

80. Rajan A, Vilas V, Philip D. Studies on catalytic, antioxidant, antibacterial and anticancer activities of biogenic gold nanoparticles. J Mol Liq. 2015;212:331-339. doi:10.1016/j.molliq.2015.09.013

81. Cabrera FC, Mohan H, Dos Santos RJ, et al. Green synthesis of gold nanoparticles with self-sustained natural rubber membranes. J Nanomater. 2013;2013:110. doi:10.1155/2013/710902

82. Aromal SA, Vidhu V, Philip D. Green synthesis of well-dispersed gold nanoparticles using macrotyloma uniflorum. Spectroc Acta Pt A-Molec Biomolec Spectr. 2012;85(1):99-104. doi:10.1016/j. saa.2011.09.035

83. Zayed MF, Eisa WH. Phoenix dactylifera L. leaf extract phytosynthesized gold nanoparticles; controlled synthesis and catalytic activity. Spectroc Acta Pt A-Molec Biomolec Spectr. 2014;121:238-244. doi:10.1016/j.saa.2013.10.092

84. Opris R, Tatomir C, Olteanu D, et al. The effect of sambucus nigra L. extract and phytosinthesized gold nanoparticles on diabetic rats. Colloid Surf B-Biointerfaces. 2017;150:192-200. doi:10.1016/j.colsurfb.2016.11.033

85. Huo Y, Singh P, Kim YJ, et al. Biological synthesis of gold and silver chloride nanoparticles by glycyrrhiza uralensis and in vitro applications. Artif Cell Nanomed Biotechnol. 2017:1-13.

86. Mata R, Bhaskaran A, Sadras SR. Green-synthesized gold nanoparticles from plumeria alba flower extract to augment catalytic degradation of organic dyes and inhibit bacterial growth. Particuology. 2016;24:78-86. doi:10.1016/j.partic.2014.12.014

87. Anand K, Gengan R, Phulukdaree A, Chuturgoon A. Agroforestry waste moringa oleifera petals mediated green synthesis of gold nanoparticles and their anti-cancer and catalytic activity. $J$ Ind Eng Chem. 2015;21:1105-1111. doi:10.1016/j.jiec.2014.05.021

88. Ghoreishi SM, Behpour M, Khayatkashani M. Green synthesis of silver and gold nanoparticles using rosa damascena and its primary application in electrochemistry. Physica E. 2011;44 (1):97-104. doi:10.1016/j.physe.2011.07.008

89. Lee KX, Shameli K, Miyake M, et al. Green synthesis of gold nanoparticles using aqueous extract of garcinia mangostana fruit peels. J Nanomater. 2016;2016:1-7.

90. Rajan A, Rajan AR, Philip D. Elettaria cardamomum seed mediated rapid synthesis of gold nanoparticles and its biological activities. OpenNano. 2017;2:1-8. doi:10.1016/j.onano.2016.11.002

91. Aromal SA, Philip D. Green synthesis of gold nanoparticles using trigonella foenum-graecum and its size-dependent catalytic activity. Spectroc Acta Pt A-Molec Biomolec Spectr. 2012;97:1-5. doi:10.1016/j.saa.2012.05.083
92. Alharbi NS, Bhakyaraj K, Gopinath K, et al. Gum-mediated fabrication of eco-friendly gold nanoparticles promoting cell division and pollen germination in plant cells. J Clust Sci. 2016;28 (1): $1-11$.

93. Tetgure SR, Borse AU, Sankapal BR, Garole VJ, Garole DJ. Green biochemistry approach for synthesis of silver and gold nanoparticles using ficus racemosa latex and their $\mathrm{pH}$-dependent binding study with different amino acids using UV/Vis absorption spectroscopy. Amino Acids. 2015;47(4):757-765. doi:10.1007/ s00726-014-1906-9

94. Manjunath HM, Joshi CG, Raju NG. Biofabrication of gold nanoparticles using marine endophytic fungus-penicillium citrinum. IET Nanobiotechnol. 2016;11(1):40-44. doi:10.1049/ietnbt.2016.0065

95. Qu Y, Pei X, Shen W, et al. Biosynthesis of gold nanoparticles by aspergillum sp. WL-Au for degradation of aromatic pollutants. Physica E. 2017;88:133-141. doi:10.1016/j.physe.2017.01.010

96. Barabadi H, Honary S, Mohammadi MA, et al. Green chemical synthesis of gold nanoparticles by using penicillium aculeatum and their scolicidal activity against hydatid cyst protoscolices of echinococcus granulosus. Environ Sci Pollut Res. 2017;24 (6): $1-11$.

97. Vala AK. Exploration on green synthesis of gold nanoparticles by a marine-derived fungus aspergillus sydowii. Environ Prog Sustain Energy. 2015;34(1):194-197. doi:10.1002/ep.v34.1

98. Shen W, Qu Y, Pei X, et al. Catalytic reduction of 4-nitrophenol using gold nanoparticles biosynthesized by cell-free extracts of aspergillus sp. WL-Au. J Hazard Mater. 2017;321:299-306. doi:10.1016/j.jhazmat.2016.07.051

99. Vetchinkina EP, Loshchinina EA, Vodolazov IR, Kursky VF, Dykman LA, Nikitina VE. Biosynthesis of nanoparticles of metals and metalloids by basidiomycetes. Preparation of gold nanoparticles by using purified fungal phenol oxidases. Appl Microbiol Biotechnol. 2016;1-16.

100. Lee K, Nagajyothi P, Sreekanth T, Park S. Eco-friendly synthesis of gold nanoparticles (AuNPs) using inonotus obliquus and their antibacterial, antioxidant and cytotoxic activities. $J$ Ind Eng Chem. 2014;26:67-72. doi:10.1016/j.jiec.2014.11.016

101. Firdhouse MJ, Lalitha P. Flower-shaped gold nanoparticles synthesized using kedrostis foetidissima and their antiproliferative activity against bone cancer cell lines. Int J Ind Chem. 2016;7 (4):347-358. doi:10.1007/s40090-016-0098-4

102. Medina Cruz D, Mi G, Webster TJ. Synthesis and characterization of biogenic selenium nanoparticles with antimicrobial properties made by staphylococcus aureus, methicillin-resistant staphylococcus aureus (MRSA), escherichia coli, and pseudomonas aeruginosa. J Biomed Mater Res Part A. 2018;106(5):1400-1412. doi:10.1002/jbm.a.36347

103. Kumar CG, Poornachandra Y, Mamidyala SK. Green synthesis of bacterial gold nanoparticles conjugated to resveratrol as delivery vehicles. Colloid Surf B-Biointerfaces. 2014;123:311-317. doi:10.1016/j.colsurfb.2014.09.032

104. Otari SV, Kumar M, Kim I-W, Lee JH, Lee J-K. Rapid, thermostable antimicrobial peptide-mediated synthesis gold nanoparticles as highly efficient charge trapping medium for sol-gel-derived thin film. Mater Lett. 2017;188:375-378. doi:10.1016/j.matlet.2016.11.104

105. Rangnekar A, Sarma TK, Singh AK, Deka J, Ramesh A, Chattopadhyay A. Retention of enzymatic activity of $\alpha$-amylase in the reductive synthesis of gold nanoparticles. Langmuir. 2007;23(10):5700-5706. doi:10.1021/1a062749e

106. Geng X, Grove TZ. Repeat protein mediated synthesis of gold nanoparticles: effect of protein shape on the morphological and optical properties. RSC Adv. 2015;5(3):2062-2069. doi:10.1039/ C4RA12014K 
107. Pienpinijtham P, Thammacharoen C, Ekgasit S. Green synthesis of size controllable and uniform gold nanospheres using alkaline degradation intermediates of soluble starch as reducing agent and stabilizer. Macromol Res. 2012;20(12):1281-1288. doi:10.1007/ s13233-012-0162-7

108. Philip D. Honey mediated green synthesis of gold nanoparticles. Spectroc Acta Pt A-Molec Biomolec Spectr. 2009;73(4):650-653. doi:10.1016/j.saa.2009.03.007

109. Huang C, Chen S, Pan JR. Optimal condition for modification of chitosan: a biopolymer for coagulation of colloidal particles. Water Res. 2000;34(3):1057-1062. doi:10.1016/S0043-1354(99) 00211-0

110. Esther J, Sridevi V. Synthesis and characterization of chitosan-stabilized gold nanoparticles through a facile and green approach. Gold Bull. 2016;1-5.

111. Saha SK, Roy P, Mondal MK, et al. Development of chitosan based gold nanomaterial as an efficient antifilarial agent: a mechanistic approach. Carbohydr Polym. 2017;157:1666-1676. doi:10.1016/j. carbpol.2016.11.047

112. Chen $\mathrm{Y}, \mathrm{Wu} \mathrm{X}, \mathrm{Lv} \mathrm{L}$, et al. Enhancing reducing ability of $\alpha$-zein by fibrillation for synthesis of Au nanocrystals with continuous flow catalysis. J Colloid Interface Sci. 2017;491:37-43. doi:10.1016/j.jcis.2016.09.081

113. Bollella P, Schulz C, Favero G, et al. Green synthesis and characterization of gold and silver nanoparticles and their application for development of a third generation lactose biosensor. Electroanalysis. 2017;29(1):77-86. doi:10.1002/elan.v29.1

114. Lee J, Kim HY, Zhou H, et al. Green synthesis of phytochemical-stabilized Au nanoparticles under ambient conditions and their biocompatibility and antioxidative activity. J Mater Chem. 2011;21(35):13316-13326. doi:10.1039/c1jm11592h

115. Liu J, Peng Q. Protein-gold nanoparticle interactions and their possible impact on biomedical applications. Acta Biomater. 2017;55:13-27. doi:10.1016/j.actbio.2017.03.055

116. Peng $\mathrm{Q}, \mathrm{Mu} \mathrm{H}$. The potential of protein-nanomaterial interaction for advanced drug delivery. $J$ Controlled Release. 2016;225:121-132. doi:10.1016/j.jconrel.2016.01.041

117. Mironava T, Hadjiargyrou M, Simon M, Jurukovski V, Rafailovich MH. Gold nanoparticles cellular toxicity and recovery: effect of size, concentration and exposure time. Nanotoxicology. 2010;4(1):120-137. doi:10.3109/174353909 03471463

118. Elia P, Zach R, Hazan S, Kolusheva S, Porat ZE, Zeiri Y. Green synthesis of gold nanoparticles using plant extracts as reducing agents. Int J Nanomed. 2014;9:4007.

119. Iram F, Iqbal MS, Athar MM, Saeed MZ, Yasmeen A, Ahmad R. Glucoxylan-mediated green synthesis of gold and silver nanoparticles and their phyto-toxicity study. Carbohydr Polym. 2014;104:29-33. doi:10.1016/j.carbpol.2014.01.002

120. De Jong WH, Hagens WI, Krystek P, Burger MC, Sips AJ, Geertsma RE. Particle size-dependent organ distribution of gold nanoparticles after intravenous administration. Biomaterials. 2008;29(12):1912-1919. doi:10.1016/j.biomaterials.2007.12.037

121. Sadauskas E, Danscher G, Stoltenberg M, Vogel U, Larsen A, Wallin H. Protracted elimination of gold nanoparticles from mouse liver. Nanomed Nanotechnol Biol Med. 2009;5 (2):162-169. doi:10.1016/j.nano.2008.11.002

122. Cho K, Wang X, Nie S, Shin DM. Therapeutic nanoparticles for drug delivery in cancer. Clin Cancer Res. 2008;14(5):1310-1316. doi:10.1158/1078-0432.CCR-07-1441

123. Tang L, Yang X, Yin Q, et al. Investigating the optimal size of anticancer nanomedicine. Proc Natl Acad Sci USA. 2014;111 (43):15344-15349. doi:10.1073/pnas.1411499111

124. Farokhzad OC, Langer R. Impact of nanotechnology on drug delivery. ACS Nano. 2009;3(1):16-20. doi:10.1021/nn900002m
125. Gratton SE, Ropp PA, Pohlhaus PD, et al. The effect of particle design on cellular internalization pathways. Proc Natl Acad Sci USA. 2008;105(33):11613-11618. doi:10.1073/pnas.0801763105

126. Yew YP, Shameli K, Miyake M, et al. Green biosynthesis of superparamagnetic magnetite Fe $3 \mathrm{O} 4$ nanoparticles and biomedical applications in targeted anticancer drug delivery system: a review. Arab J Chem. 2018. doi:10.1016/j.arabjc.2018.04.013

127. Dreaden EC, Austin LA, Mackey MA, El-Sayed MA. Size matters: gold nanoparticles in targeted cancer drug delivery. Ther Deliv. 2012;3(4):457-478. doi:10.4155/tde.12.21

128. Li L, Yang Q, Zhou Z, Zhong J, Huang Y. Doxorubicin-loaded, charge reversible, folatemodified HPMAcopolymer conjugates foractive cancercell targeting. Biomaterials. 2014;35:5171-5187.

129. Nakkala JR, Mata R, Bhagat E, Sadras SR. Green synthesis of silver and gold nanoparticles from gymnema sylvestre leaf extract: study of antioxidant and anticancer activities. $J$ Nanopart Res. 2015;17(3):1-15. doi:10.1007/s11051-0152957-x

130. Mukherjee S, Ghosh S, Das DK, et al. Gold-conjugated green tea nanoparticles for enhanced anti-tumor activities and hepatoprotection-synthesis, characterization and in vitro evaluation. $J \quad$ Nutr Biochem. 2015;26(11):1283-1297. doi:10.1016/j. jnutbio.2015.06.003

131. Mukherjee S, Dasari M, Priyamvada S, Kotcherlakota R, Bollu VS, Patra CR. A green chemistry approach for the synthesis of gold nanoconjugates that induce the inhibition of cancer cell proliferation through induction of oxidative stress and their in vivo toxicity study. $J$ Mat Chem B. 2015;3(18):3820-3830. doi:10.1039/C5TB00244C

132. Muniyappan N, Nagarajan N. Green synthesis of gold nanoparticles using curcuma pseudomontana essential oil, its biological activity and cytotoxicity against human ductal breast carcinoma cells T47D. J Environ Chem Eng. 2014;2(4):2037-2044. doi:10.1016/j.jece.2014.03.004

133. Patil MP, Ngabire D, Thi HHP, Kim M-D, Kim G-D. Eco-friendly synthesis of gold nanoparticles and evaluation of their cytotoxic activity on cancer cells. J Clust Sci. 2016;1-14.

134. Balasubramani G, Ramkumar R, Raja RK, Aiswarya D, Rajthilak C, Perumal P. Albizia amara roxb. mediated gold nanoparticles and evaluation of their antioxidant, antibacterial and cytotoxic properties. J Clust Sci. 2017;1-17.

135. Devi PR, Kumar CS, Selvamani P, Subramanian N, Ruckmani K. Synthesis and characterization of Arabic gum capped gold nanoparticles for tumor-targeted drug delivery. Mater Lett. 2015;139:241-244. doi:10.1016/j.matlet.2014.10.010

136. Vijayashree I, Niranjana P, Prabhu G, Sureshbabu V, Manjanna J. Conjugation of Au nanoparticles with chlorambucil for improved anticancer activity. J Clust Sci. 2017;28(1):133-148. doi:10.1007/ s10876-016-1053-4

137. Ganeshkumar M, Sathishkumar M, Ponrasu T, Dinesh MG, Suguna L. Spontaneous ultra fast synthesis of gold nanoparticles using punica granatum for cancer targeted drug delivery. Colloid Surf B-Biointerfaces. 2013;106:208-216. doi:10.1016/j. colsurfb.2013.01.035

138. Elahi N, Kamali M, Baghersad MH. Recent biomedical applications of gold nanoparticles: a review. Talanta. 2018;184:537-556. doi:10.1016/j.talanta.2018.02.088

139. Tian L, Zhao W, Li L, Tong Y, Peng G, Li Y. Multi-talented applications for cell imaging, tumor cells recognition, patterning, staining and temperature sensing by using egg white-encapsulated gold nanoclusters. Sensors Actuators B. 2017;240:114-124. doi:10.1016/j.snb.2016.08.147

140. Abhijith KS, Thakur MS. Application of green synthesis of gold nanoparticles for sensitive detection of aflatoxin B1 based on metal enhanced fluorescence. Anal Methods. 2012;4 (12):4250-4256. doi:10.1039/c2ay25979f 
141. Rao KJ, Paria S. Green synthesis of gold nanoparticles using aqueous aegle marmelos leaf extract and their application for thiamine detection. RSC Adv. 2014;4(54):28645-28652. doi: $10.1039 / \mathrm{c} 4 \mathrm{ra} 03883 \mathrm{e}$

142. Bahram M, Mohammadzadeh E. Green synthesis of gold nanoparticles with willow tree bark extract: a sensitive colourimetric sensor for cysteine detection. Anal Methods. 2014;6 (17):6916-6924. doi:10.1039/C4AY01362J

143. Qin L, Zeng G, Lai C, et al. "Gold rush" in modern science: fabrication strategies and typical advanced applications of gold nanoparticles in sensing. Coord Chem Rev. 2018;359:1-31. doi:10.1016/j.ccr.2018.01.006

144. Lu S, Wang S, Chen C, Sun J, Yang X. Enzyme-free aptamer/ AuNPs-based fluorometric and colorimetric dual-mode detection for ATP. Sensors Actuators B. 2018;265:67-74. doi:10.1016/j. snb.2018.02.003

145. Hemalatha T, Prabu P, Gunadharini DN, Gowthaman MK. Fabrication and characterization of dual acting oleyl chitosan functionalised iron oxide/gold hybrid nanoparticles for MRI and CT imaging. Int $J$ Biol Macromol. 2018;112:250-257. doi:10.1016/j.ijbiomac.2018.01.159

146. Kumar KM, Mandal BK, Sinha M, Krishnakumar V. Terminalia chebula mediated green and rapid synthesis of gold nanoparticles. Spectroc Acta Pt A-Molec Biomolec Spectr. 2012;86:490-494. doi:10.1016/j.saa.2011.11.001

147. Dhayalan M, Denison MIJ, Krishnan K. In vitro antioxidant, antimicrobial, cytotoxic potential of gold and silver nanoparticles prepared using embelia ribes. Nat Prod Res. 2017;31(4):465-468. doi:10.1080/14786419.2016.1166499

148. Suganya KU, Govindaraju K, Kumar VG, et al. Blue green alga mediated synthesis of gold nanoparticles and its antibacterial efficacy against gram positive organisms. Mater Sci Eng C-Mater Biol Appl. 2015;47:351-356. doi:10.1016/j.msec.2014.11.043

149. Abdel-Raouf N, Al-Enazi NM, Ibraheem IB. Green biosynthesis of gold nanoparticles using galaxaura elongata and characterization of their antibacterial activity. Arab J Chem. 2017;10 (Supplement 2):S3029-S39. doi:10.1016/j.arabjc.2013.11.044

150. Vanaraj S, Jabastin J, Sathiskumar S, Preethi K. Production and characterization of bio-AuNPs to induce synergistic effect against multidrug resistant bacterial biofilm. J Clust Sci. 2017;28 (1):227-244. doi:10.1007/s10876-016-1081-0

151. MubarakAli D, Thajuddin N, Jeganathan K, Gunasekaran M. Plant extract mediated synthesis of silver and gold nanoparticles and its antibacterial activity against clinically isolated pathogens. Colloid Surf B-Biointerfaces. 2011;85(2):360-365. doi:10.1016/j. colsurfb.2011.03.009

152. Annamalai A, Christina V, Sudha D, Kalpana M, Lakshmi P. Green synthesis, characterization and antimicrobial activity of Au NPs using euphorbia hirta L. leaf extract. Colloid Surf B-Biointerfaces. 2013;108:60-65. doi:10.1016/j.colsurfb.2013.02.012

153. Reddy GR, Morais AB, Gandhi NN. Green synthesis, characterization and in vitro antibacterial studies of gold nanoparticles by using senna siamea plant seed aqueous extract at ambient conditions. Asian J Chem. 2013;25(15):8541-8544.
154. Kuppusamy P, Yusoff MM, Ichwan SJ, Parine NR, Maniam GP, Govindan N. Commelina nudiflora L. edible weed as a novel source for gold nanoparticles synthesis and studies on different physical-chemical and biological properties. J Ind Eng Chem. 2014;27:59-67. doi:10.1016/j.jiec.2014.11.045

155. Annavaram V, Posa VR, Vijaya Lakshmi D, Sumalatha J, Somala AR. Terminalia bellirica fruit extract mediated synthesis of gold nanoparticles (AuNPs) and studies on antimicrobial and antioxidant activity. Synth React Inorg Met-Org Nano-Metal Chem. 2016;47(5):681-687. doi:10.1080/15533174.2016.1212219

156. Karthika V, Arumugam A, Gopinath K, et al. Guazuma ulmifolia bark-synthesized $\mathrm{Ag}, \mathrm{Au}$ and $\mathrm{Ag} / \mathrm{Au}$ alloy nanoparticles: photocatalytic potential, DNA/protein interactions, anticancer activity and toxicity against 14 species of microbial pathogens. J Photochem Photobiol B. 2017;167:189-199. doi:10.1016/j. jphotobiol.2017.01.008

157. Islam NU, Jalil K, Shahid M, Muhammad N, Rauf A. Pistacia integerrima gall extract mediated green synthesis of gold nanoparticles and their biological activities. Arab J Chem. 2015.

158. Bankar A, Joshi B, Kumar AR, Zinjarde S. Banana peel extract mediated synthesis of gold nanoparticles. Colloid Surf B-Biointerfaces. 2010;80(1):45-50. doi:10.1016/j. colsurfb.2010.05.029

159. Dykman L, Khlebtsov N. Gold nanoparticles in biomedical applications: recent advances and perspectives. Chem Soc Rev. 2012;41(6):2256-2282.

160. Kim D-Y, Kim M, Shinde S, Sung J-S, Ghodake G. Cytotoxicity and antibacterial assessment of gallic acid capped gold nanoparticles. Colloid Surf B-Biointerfaces. 2017;149:162-167. doi:10.1016/j.colsurfb.2016.10.017

161. Fratoddi I, Venditti I, Cametti C, Russo M. Gold nanoparticles and gold nanoparticle-conjugates for delivery of therapeutic molecules. Progress and challenges. J Mat Chem B. 2014;2 (27):4204-4220. doi:10.1039/C4TB00383G

162. Li Y, Wu T-Y, Chen S-M, Ali MA, AlHemaid FM. Green synthesis and electrochemical characterizations of gold nanoparticles using leaf extract of magnolia kobus. Int $J$ Electrochem Sci. 2012;7(12):12742-12751.

163. Wang R, Deng J, He D, et al. PEGylated hollow gold nanoparticles for combined X-ray radiation and photothermal therapy in vitro and enhanced CT imaging in vivo. Nanomed Nanotechnol Biol Med. 2019;16:195-205. doi:10.1016/j. nano.2018.12.005

164. Karami P, Khoshsafar H, Johari-Ahar M, Arduini F, Afkhami A, Bagheri H. Colorimetric immunosensor for determination of prostate specific antigen using surface plasmon resonance band of colloidal triangular shape gold nanoparticles. Spectroc Acta Pt A-Molec Biomolec Spectr. 2019;222:117218. doi:10.1016/j. saa.2019.117218

165. Shende P, Kasture P, Gaud R. Nanoflowers: the future trend of nanotechnology for multi-applications. Artif Cell Nanomed Biotechnol. 2018;46(sup1):413-422. doi:10.1080/21691401.20 18.1428812
International Journal of Nanomedicine

\section{Publish your work in this journal}

The International Journal of Nanomedicine is an international, peerreviewed journal focusing on the application of nanotechnology in diagnostics, therapeutics, and drug delivery systems throughout the biomedical field. This journal is indexed on PubMed Central, MedLine, CAS, SciSearch ${ }^{\mathbb{R}}$, Current Contents ${ }^{\mathbb{R}} /$ Clinical Medicine, $^{2}$
Journal Citation Reports/Science Edition, EMBase, Scopus and the Elsevier Bibliographic databases. The manuscript management system is completely online and includes a very quick and fair peer-review system, which is all easy to use. Visit http://www.dovepress.com/ testimonials.php to read real quotes from published authors. 